\title{
Evaluation of in-vivo anti-Salmonella activity of Uvaria chamae, Lantana camara and Phyllantus amarus used in Benin, West Africa
}

Boris Legba ${ }^{1,2}$, Victorien Dougnon ${ }^{1 *} \mathbb{D}$, Yossounon Chabi ${ }^{3}$, Carène Gbaguidi ${ }^{1}$, Alidah Aniambossou', Esther Deguenon ${ }^{1,2}$, Jacques Dougnon ${ }^{1}$, Marc Kpodekon ${ }^{4}$ and Lamine Baba-Moussa ${ }^{2}$

\begin{abstract}
Background: Uvaria chamae (Annonaceae), Phyllantus amarus (Phyllantaceae) and Lantana camara (Verbenaceae) are empirically alleged to be used as Beninese medicinal plants in the treatment of salmonellosis. This study aimed to produce scientific data on in vitro and in vivo efficacy of Uvaria chamae, Lantana camara and Phyllantus amarus on multiresistant Salmonella spp isolated in Benin.

Results: After performing in vitro tests on aqueous and ethanolic extracts of these plants, only the aqueous extract of Uvaria chamae (leaves) showed the best anti-Salmonella's activity and was used for this in vivo experiment. The induction of salmonellosis revealed $9 \times 10^{8} \mathrm{CFU} / \mathrm{ml}$ was the optimal concentration triggering and maintaining symptoms in chicks. This infective concentration was used for in vivo assessment. Twenty-four hours post inoculation, the symptoms of salmonellosis (wet cloaca, diarrhea stools and somnolence) were observed in infected groups. After 7 days of treatment, the reduction of bacterial load at $100 \mathrm{mg} / \mathrm{L}, 200 \mathrm{mg} / \mathrm{L}, 400 \mathrm{mg} / \mathrm{L}$ of the extract was respectively 85\%, 52.38\% and 98\% for Uvaria chamae, Phyllantus amarus and Lantana camara in the chick's groups infected with Salmonella Typhimurium ATCC 14028. On the other hand, colistin completely cancelled the bacterial load (reduction rate of 100\%).

With the groups infected with Salmonella spp (virulent strain), the reduction rate of bacterial load at $100 \mathrm{mg} / \mathrm{L}, 200$ $\mathrm{mg} / \mathrm{L}, 400 \mathrm{mg} / \mathrm{L}$ of extract was 0\%, 98.66\%, and 99.33\%. The extracts at 200 and $400 \mathrm{mg} / \mathrm{L}$ were more active than colistin, which reduced the bacterial load by $33.33 \%$.

The toxicity tests did not show any negative effect of Colistin and the Uvaria chamae's extract on the biochemical and hematological parameters of the chicks.

Conclusion: The aqueous extract of Uvaria chamae is active in vitro and in vivo on multiresistant strains of Salmonella enterica. This plant is a good candidate for the development of an improved traditional medicine for the management of salmonellosis.
\end{abstract}

Keywords: Salmonella Typhimurium ATCC 14028, Public health, Salmonellosis, Uvaria chamae, Improved traditional Medicine

\footnotetext{
* Correspondence: victorien.dougnon@gmail.com

${ }^{1}$ Research Unit in Applied Microbiology and Pharmacology of natural

substances, Research Laboratory in Applied Biology, Polytechnic School of

Abomey-Calavi, University of Abomey-Calavi, Cotonou, Benin

Full list of author information is available at the end of the article
}

(c) The Author(s). 2020 Open Access This article is distributed under the terms of the Creative Commons Attribution 4.0 International License (http://creativecommons.org/licenses/by/4.0/), which permits unrestricted use, distribution, and reproduction in any medium, provided you give appropriate credit to the original author(s) and the source, provide a link to the Creative Commons license, and indicate if changes were made. The Creative Commons Public Domain Dedication waiver (http://creativecommons.org/publicdomain/zero/1.0/) applies to the data made available in this article, unless otherwise stated. 


\section{Background}

Salmonella spp. is one of the major causes of foodborne illness worldwide. This germ is the source of zoonotic infections in humans and some animals. Transmission to humans can occur from contaminated food of animal origin. Pork, poultry and meat products are often cited [1].

Salmonella spp. belongs to the Enterobacteriaceae family. It is a Gram- bacilli and facultative anaerobic bacterium. The genus is divided into three main species including Salmonella enterica, Salmonella bongori and Salmonella subterranean [2]. It is one of four main causes of diarrheal diseases worldwide [3]. There were about 94 million cases of gastroenteritis with 155,000 deaths globally every year [4]. Out of these cases, it is considered that 80.3 million were foodborne origin [5]. In poultry, the epidemiologically important serotypes associated with the majority of human salmonellosis are Salmonella Enteritidis, Salmonella Typhimurium, Salmonella Newport and Salmonella Heidelberg [6-9].

The emergence of multiresistance of Salmonella strains towards reference antibiotics such as fluoroquinolones and third-generation cephalosporins became a public health problem worldwide [10-13]. As an alternative to antimicrobial resistance, exploration of medicinal plants with anti-Salmonella activity is becoming very common in West Africa. In vitro evidence of antibacterial activity of plant extracts on Salmonella strains has been demonstrated [14] but there is a few data about in vivo efficacy of medicinal plants against this bacteria.

The difficulty of choosing a suitable study model, the complexity of such research work, and the still limited data on the physiology of Salmonella strains could explain this situation. This study aimed to the experimental induction of salmonellosis in chicks as animals' models. These data can be a good starting point for in vivo efficacy testing of herbal extracts on Salmonella spp. Indeed, promoting medicinal plants used in the traditional treatment of salmonellosis involves a structured approach. At this time, an ethnopharmacological survey revealed 57 species of medicinal plants used in the treatment of salmonellosis in Benin [15]. Based on quotation frequency and literary data, Phyllantus amarus, Senna siamea, Uvaria chamae and Lantana camara have been selected. Toxicological, chemical and antibacterial (to ten enteropathogens) characterization have been done. This study showed interesting contents in polyphenols and flavonoids and an effective antibacterial activity at $100 \mathrm{mg} / \mathrm{mL}$ with Minimal Inhibitory Concentration (MIC) between 100 and $25 \mathrm{mg} / \mathrm{mL}$ and inhibition diameters between 7.5 and $21 \mathrm{~mm}$ [16].

With these results, it was found necessary to evaluate the in vitro and in vivo efficacy of extracts of Uvaria chamae, Phyllantus amarus and Lantana camara on multiresistant Salmonella spp isolated in Benin.

\section{Results}

In vitro anti-Salmonella activity of Uvaria chamae, Phyllantus amarus and Lantana camara

Salmonella Typhimurium ATCC 14028 was sensitive to aqueous extract of Uvaria chamae (leaves), ethanolic extract of Phyllantus amarus (leaves), ethanolic and aqueous extract of Lantana camara (leaves). The aqueous extract of Uvaria chamae (leaves) showed the best inhibition diameter $(9.33 \pm 2.08 \mathrm{~mm})$ (Fig. 1). There is no significant difference between inhibition diameters $(P \geq$ $0.05)$ of active extracts.

Figure 2 presents antibacterial activity of aqueous and ethanolic extracts of Uvaria chamae, Phyllantus amarus and Lantana camara on multiresistant strains of Salmonella spp isolated in Benin. Out of ethanolic extract (roots) of Uvaria chamae, all extracts showed variable susceptibility to multiresistant strains of Salmonella spp. Leaves aqueous extract of Uvaria chamae was active on $90 \%$ of Salmonella spp. Root aqueous extract of Uvaria chamae showed the best inhibition diameter (13 $\pm 1 \mathrm{~mm}$ on P19 Salmonella spp).

The Minimum Inhibitory Concentration (MIC), the Minimum Bactericidal Concentration (MBC) and the antibiotic potency (ap) of the plant extracts studied on the tested strains are summarized in Table 1. MIC range from 1.625 (Leaves ethanolic extract of Uvaria chamae on P17 Salmonella spp) to $100 \mathrm{mg} / \mathrm{ml}$. Leaves aqueous extract of Uvaria chamae was bacteriostatic on Salmonella Typhimurium ATCC 14028 and Salmonella spp. P19.

\section{In vivo anti-Salmonella activity of aqueous extracts (leaves) of Uvaria chamae using chick models Preliminary test}

This step aimed to choose the optimal effective concentration of inoculum for Salmonella's induction. Twenty-four hours after infection, wet cloaca and diarrhea stools were detected in groups 1,2 and 3 infected with $3 \times 10^{8} \mathrm{CFU} / \mathrm{ml}$ (Concentration 1), $6 \times 10^{8}$ $\mathrm{CFU} / \mathrm{ml}$ (Concentration 2), $9 \times 10^{8} \mathrm{CFU} / \mathrm{ml}$ (Concentration 3) respectively whereas these symptoms were absent in group 4, which received distilled water only. These symptoms were present until the $10^{\text {th }}$ day of observation in the group 3 while they disappeared between the fifth and the $7^{\text {th }}$ day in the group 2 (Table 2). However, no deaths were recorded. Salmonella spp. was investigated in faecal samples to support clinical observations. The strains were detected in chicks of group 2 and 3, 3 days after salmonellosis induction. They were present till the ninth day for group 3 whereas they disappeared from feces on the sixth day for group 2 (Table 3). On the ninth day, a bacterial count was made on the faeces samples to assess the bacterial load. The results are shown in Table 4. 


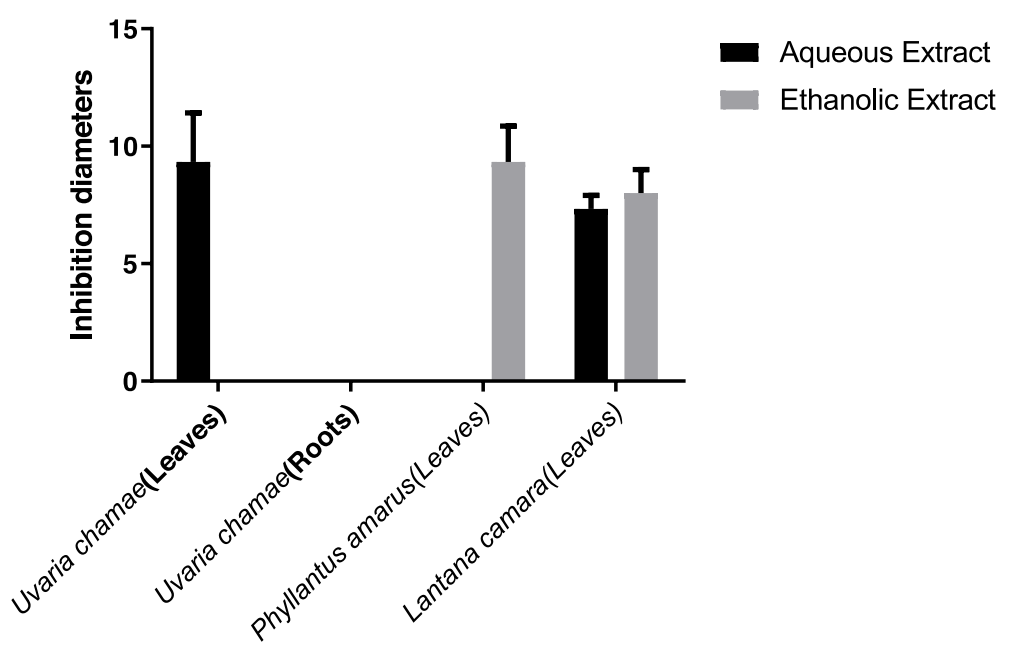

Fig. 1 Antibacterial activity of aqueous and ethanolic extracts of Uvaria chamae, Phyllantus amarus and Lantana camara on Salmonella Typhimurium ATCC 14028

Clinical observations suggest that only $9 \times 10^{8} \mathrm{UFC} / \mathrm{ml}$ could trigger and maintain the symptoms of salmonellosis.

In vivo efficacy of leaves aqueous extract of $U$. chamae on Salmonella Typhimurium ATCC 14028 (reference strain) and Salmonella spp. P19 (virulent strain)

Twenty-four hours after induction, symptoms were detected in all infected chicks. Diarrheal stools were abundant. The cloacae of the chicks were wet and somnolence was noticed in some chicks (Tables 5, 6, 7, 8, 9 and 10). During the 9 days of monitoring, including 7 days of treatment, these symptoms evolved considerably according to the groups. They remained persistent in infected and untreated chicks (group 2). However, diarrhea was slightly reduced at the last days of monitoring, indicating a progression of the disease to asymptomatic carriage (Tables 7 and 8).

Throughout the monitoring, there was a progressive increase in the weight of the chicks of all the groups (Figs. 3 and 4). For chicks infected by Salmonella Typhimurium ATCC 14028, there was no significant difference in weight change compared to other groups $(p \geq 0.05)$ (Fig. 3). Same observation was done in chicks infected with Salmonella spp. P19 (virulent strain) $(p \geq$ 0.05) (Fig. 4).

Three days after infection with Salmonella Typhimurium, the bacterial load of Salmonella increased in all infected chicks, but differentially according to the groups. The bacterial load at day 3 was in the range 2000-30, $000 \mathrm{CFU} / \mathrm{g}$. Treatment of the chicks with the extracts and colistin started at day 3 and continued until day 9 . During treatment, the bacterial load gradually decreased in group 3 treated with colistin and disappeared on Day 9. In group 2 (infected and untreated), the bacterial load decreased slightly between the third and sixth day
(11,000 to $10,000 \mathrm{CFU} / \mathrm{g})$ before undergoing a considerable increase on the ninth day $(10,000$ to 16,000 $\mathrm{CFU} / \mathrm{g})$. In groups 4,6 respectively treated with 100 and $400 \mathrm{mg} / \mathrm{l}$ of the extract, the bacterial load was first increased before falling down on day 9. In group 5 (treated with the extract at $200 \mathrm{mg} / \mathrm{l}$ ), a gradual decline from the 3rd to the 9th day (21,000 to 10.000 $\mathrm{CFU} / \mathrm{g}$ ) (Fig. 5) was observed. In group 1 (unfected chicks), the bacterial load remained zero.

Bacterial load reduction between the 3rd and the 9th day after the infection ( 7 days of treatment) was assessed globally and summarized in the Fig. 6 . The bacterial load increased by $45.45 \%$ in group 2 (infected and untreated). It was reduced by $100 \%$ in lot 3 (treated with colistin). Treatment with leaves aqueous extract of Uvaria chamae also showed remarkable efficacy (bacterial load reduction between 52.38 and $98 \%$ ).

Three days after infection with Salmonella spp. (virulent strain) (Fig. 7), the bacterial load of Salmonella increased in all infected chicks. The bacterial load at day 3 was in the range 3000-15,000 CFU/g. Treatment of the chicks with the extracts and colistin started on day 3 and continued until day 9. During treatment, the bacterial load gradually decreased from 1500 to $1000 \mathrm{CFU} / \mathrm{g}$ in group 3 treated with colistin. In group 2 (infected and untreated), the bacterial load decreased slightly between the third and sixth day (9000 to $3000 \mathrm{CFU} / \mathrm{g}$ ) before undergoing a considerable increase on the ninth day (3000 to 52,000 $\mathrm{CFU} / \mathrm{g})$. In groups 4,6 respectively treated with 100 and $400 \mathrm{mg} / \mathrm{l}$, the bacterial load was first increased before falling on day 9 , whereas in group 5 treated with the extract at $200 \mathrm{mg} / \mathrm{l}$, bacterial load was constant to $15,000 \mathrm{CFU} / \mathrm{g}$ between day 3 and day 6 and decreased to $200 \mathrm{CFU} / \mathrm{g}$ at day 9. In group 1 (non-infected chicks), the bacterial load remained zero. 

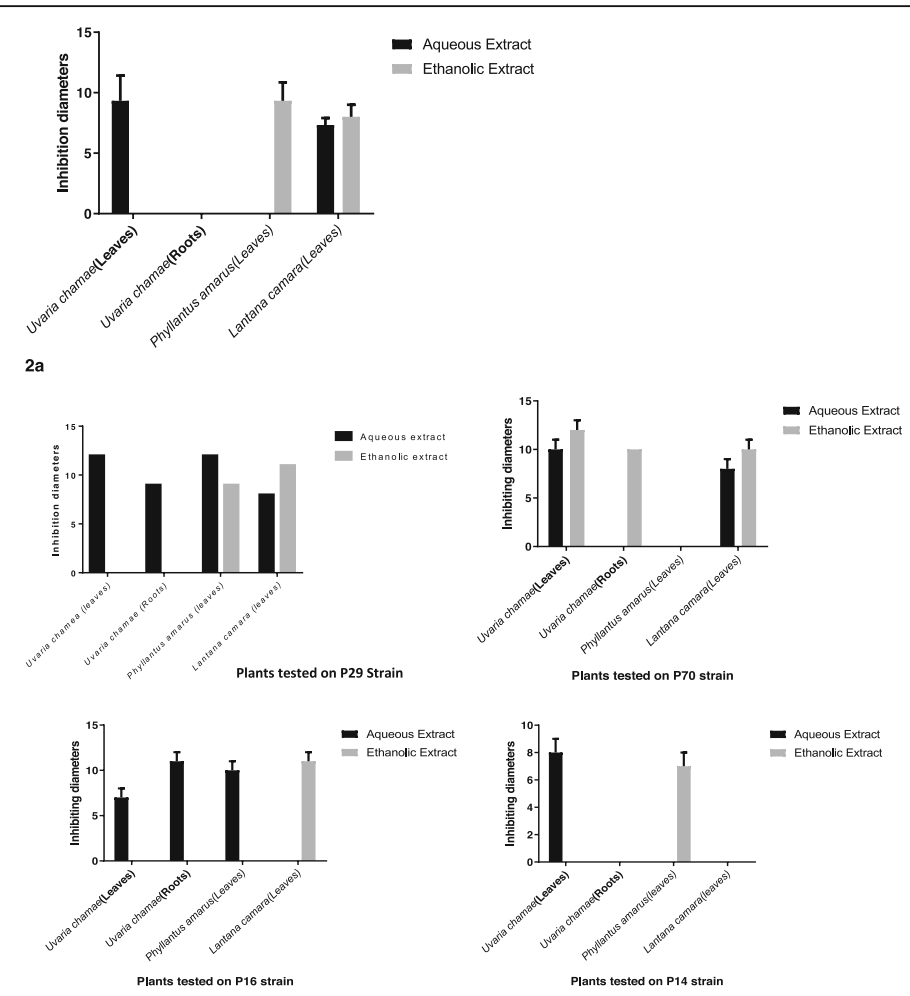

$2 b$
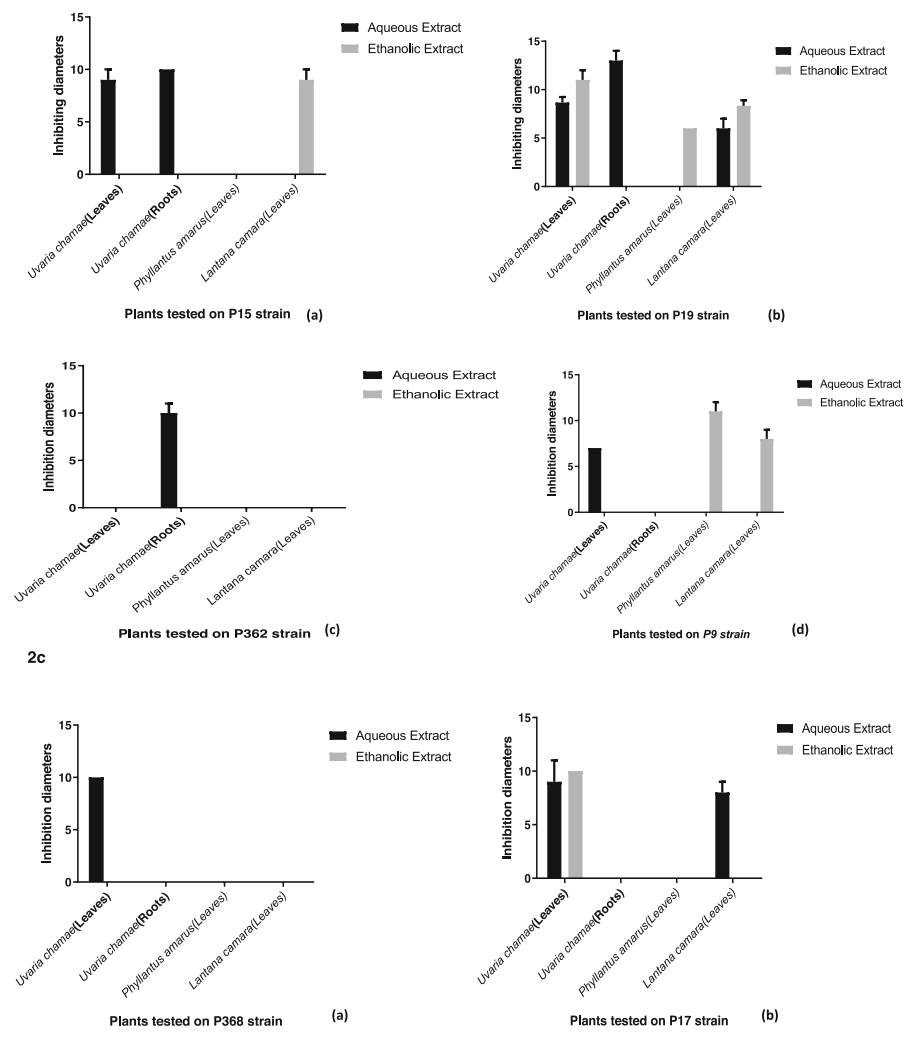

Fig. 2 Antibacterial activity of aqueous and ethanolic extracts of Uvaria chamae, Phyllantus amarus and Lantana camara on multiresistant Salmonella spp. isolated in Benin 
Table $1 \mathrm{MIC}(\mathrm{mg} / \mathrm{ml}), \mathrm{MBC}(\mathrm{mg} / \mathrm{ml})$ and a. p. of the aqueous and Ethanolic extracts of the plants on Salmonella spp.

\begin{tabular}{|c|c|c|c|c|c|c|c|c|c|c|c|c|}
\hline Extracts & Parameters & P9 & $P 70$ & P16 & P14 & P15 & P19 & P362 & P368 & P17 & $P 29$ & $S T$ \\
\hline \multirow{3}{*}{$\begin{array}{l}\text { U.Chamae } \\
\text { Leaves aqueous extract }\end{array}$} & MIC & 12.5 & 25 & 6.25 & 6.25 & 6.25 & 12.5 & - & 12.5 & 3.25 & 12.5 & 6.25 \\
\hline & $M B C$ & 100 & $>100$ & $>100$ & $>100$ & $>100$ & 100 & - & 50 & 100 & $>100$ & 100 \\
\hline & a.p. & 8 & - & - & - & - & 8 & - & 4 & 32 & - & 8 \\
\hline \multirow{3}{*}{$\begin{array}{l}\text { U.Chamae } \\
\text { Leaves ethanolic extract }\end{array}$} & $\mathrm{MIC}$ & 3.125 & - & - & - & - & 3.125 & - & - & 1.5265 & - & - \\
\hline & $M B C$ & $>100$ & - & - & - & - & $>100$ & - & - & 100 & - & - \\
\hline & a.p. & - & - & - & - & - & - & - & - & 65.51 & - & - \\
\hline \multirow{3}{*}{$\begin{array}{l}\text { U.Chamae } \\
\text { Roots aqueous extract }\end{array}$} & MIC & - & - & 50 & - & 6.25 & - & 12.5 & - & - & 25 & - \\
\hline & $\mathrm{MBC}$ & - & - & $>100$ & - & $>100$ & - & $>100$ & - & - & $>100$ & - \\
\hline & a.p. & - & - & - & - & - & - & - & - & - & - & - \\
\hline \multirow{3}{*}{$\begin{array}{l}\text { U.Chamae } \\
\text { Roots ethanolic extract }\end{array}$} & MIB & - & - & - & - & - & - & - & - & - & - & - \\
\hline & $\mathrm{MBC}$ & - & - & - & - & - & - & - & - & - & - & - \\
\hline & a.p. & - & - & - & - & - & - & - & - & - & - & - \\
\hline \multirow{3}{*}{$\begin{array}{l}\text { P. amarus } \\
\text { Leaves aqueous extract }\end{array}$} & MIC & - & - & 50 & - & - & - & 100 & - & - & 50 & - \\
\hline & $M B C$ & - & - & $>100$ & - & - & - & $>100$ & - & - & $>100$ & - \\
\hline & a.p. & - & - & - & - & - & - & - & - & - & - & - \\
\hline \multirow{3}{*}{$\begin{array}{l}\text { P.amarus } \\
\text { Leaves ethanolic extract }\end{array}$} & MIC & 6.25 & - & - & 25 & - & - & - & - & - & 12.5 & 12.5 \\
\hline & $\mathrm{MBC}$ & $>100$ & - & - & $>100$ & - & - & - & - & - & $>100$ & $>100$ \\
\hline & a.p. & - & - & - & - & - & - & - & - & - & - & - \\
\hline \multirow{3}{*}{$\begin{array}{l}\text { L.camara } \\
\text { Leaves aqueous extract }\end{array}$} & MIB & - & - & - & - & - & - & - & - & - & - & - \\
\hline & $\mathrm{MBC}$ & - & - & - & - & - & - & - & - & - & - & - \\
\hline & a.p. & - & - & - & - & - & - & - & - & - & - & - \\
\hline \multirow{3}{*}{$\begin{array}{l}\text { L.camara } \\
\text { Leaves ethanolic extract }\end{array}$} & MIB & & 6.25 & & & 3.125 & & & & & 12.5 & 12.5 \\
\hline & $\mathrm{MBC}$ & & $>100$ & & & $>100$ & & & & & $>100$ & $>100$ \\
\hline & a.p. & - & - & - & - & - & - & - & - & - & - & - \\
\hline
\end{tabular}

ST Salmonella Typhimurium ATCC 14028

MIC Minimum Inhibitory Concentration, MBC Minimum Bactericidal Concentration, a.p Antibiotic potency

Table 2 Salmonellosis Symptoms in three-day-old chicks inoculated with Salmonella Typhimurim ATCC 14028( $n=3$ for each concentration of inoculum)

\begin{tabular}{|c|c|c|c|c|c|c|c|c|c|c|c|}
\hline \multirow[t]{2}{*}{ Groups } & \multirow[t]{2}{*}{ Salmonellosis symptoms } & \multicolumn{10}{|c|}{ Days Post infection } \\
\hline & & 1 & 2 & 3 & 4 & 5 & 6 & 7 & 8 & 9 & 10 \\
\hline \multirow[t]{3}{*}{$1\left(3.010^{8} \mathrm{UFC} / \mathrm{ml}\right)$} & Wet cloaca & - & - & - & - & - & - & - & - & - & - \\
\hline & diarrheal stool & + & - & - & - & - & - & - & - & - & - \\
\hline & Somnolence & - & - & - & - & - & - & - & - & - & - \\
\hline \multirow[t]{3}{*}{$2\left(6.010^{8} \mathrm{UFC} / \mathrm{ml}\right)$} & Wet cloaca & + & + & + & + & + & - & - & - & - & - \\
\hline & diarrheal stool & + & + & + & + & + & + & + & - & - & - \\
\hline & Somnolence & - & + & - & - & - & - & - & - & - & - \\
\hline \multirow[t]{3}{*}{$3\left(9.010^{8} \mathrm{UFC} / \mathrm{ml}\right)$} & Wet cloaca & + & + & + & + & + & + & + & + & + & + \\
\hline & diarrheal stool & + & + & + & + & + & + & + & + & + & + \\
\hline & Somnolence & - & - & + & + & - & - & - & - & - & - \\
\hline \multirow[t]{3}{*}{4 (Distilled Water) } & Wet cloaca & - & - & - & - & - & - & - & - & - & - \\
\hline & diarrheal stool & - & - & - & - & - & - & - & - & - & - \\
\hline & Somnolence & - & - & - & - & - & - & - & - & - & - \\
\hline
\end{tabular}


Table 3 Salmonella detection in fecal samples of three-day-old chicks inoculated with Salmonella Typhimurim ATCC $14028(n=3$ for each concentration of inoculum)

\begin{tabular}{|c|c|c|c|c|}
\hline \multirow[t]{2}{*}{ Groups } & \multicolumn{4}{|c|}{ Detection of Salmonella at Days Post infection } \\
\hline & 0 & 3 & 6 & 9 \\
\hline G1 $\left(3.010^{8} \mathrm{UFC} / \mathrm{ml}\right)$ & - & - & - & - \\
\hline $\mathrm{G} 2\left(6.010^{8} \mathrm{UFC} / \mathrm{ml}\right)$ & - & + & - & - \\
\hline G3 $\left(9.010^{8} \mathrm{UFC} / \mathrm{ml}\right)$ & - & + & + & + \\
\hline G4 (Distilled Water) & - & - & - & - \\
\hline
\end{tabular}

Legend: Absence (-), Presence (+)

Bacterial load reduction between the 3rd and the 9th day after the infection (7 days of treatment) was assessed globally and summarized in the Fig. 8. The bacterial load increased by $477.77 \%$ (4.7 times) in group 2 (infected and untreated). It was reduced by $33.33 \%$ in lot 3 (treated with Colistin), $98.66 \%$ in group 5, 99.33\% in group 6 . The extract at $100 \mathrm{mg} / \mathrm{l}$ did not allow a reduction of the bacterial load (group 4).

\section{Effects of leaves aqueous extract of Uvaria chamae on biochemical and hematological parameters}

Effect of Leaves aqueous extract of Uvaria chamae on hematological and biochemical parameters was investigated to evaluate whether as a biologically active substance, this extract did not have a pathological effect on certain biochemical and hematological parameters. The results are shown in Figs. 9 and 10.

Uremia increased insignificantly $(p \geq 0.05)$ at day 4 in chicks which received $400 \mathrm{mg} / \mathrm{l}(4.66 \mathrm{~g} / \mathrm{l}$ to $4.99 \mathrm{~g} / \mathrm{l})$ and $100 \mathrm{mg} / \mathrm{l}(4,49 \mathrm{~g} / \mathrm{l}$ at $5.27 \mathrm{~g} / \mathrm{l})$ of extract. As for those which received $200 \mathrm{mg} / \mathrm{l}$ of extract, their uremia increased at day 7 ( $4.23 \mathrm{~g} / \mathrm{l}$ to $4.67 \mathrm{~g} / \mathrm{l})$. The creatinine concentration at day 4 increased insignificantly in chicks having $100 \mathrm{mg}$ of extract $(0.17 \mathrm{~g} / \mathrm{l}$ to $0.21 \mathrm{~g} / \mathrm{l})$ and those which received the antibiotic $(0.16 \mathrm{~g} / \mathrm{l}$ to $0.21 \mathrm{~g} / \mathrm{l})$. In chicks which received $200 \mathrm{mg}(0.16 \mathrm{~g} / \mathrm{l}$ to $0.18 \mathrm{~g} / \mathrm{l})$ and $400 \mathrm{mg}(0.17 \mathrm{~g} / \mathrm{l}$ to $0.19 \mathrm{~g} / \mathrm{l})$ of extract, their creatinine increased at day $7(p \geq 0.05))$. Same observation was done with AST and ALT (no significant variation) (Fig. 9). With hematological parameters, the same observations are made. There was no significant difference in all groups. However, the number of blood cells increased

Table 4 Salmonella count in fecal samples of three-day-old chicks inoculated with Salmonella Typhimurim ATCC 14028

\begin{tabular}{ll}
\hline Groups & Bacterial load at Day 9 (CFU/g) \\
\hline G1 $\left(3.010^{8} \mathrm{UFC} / \mathrm{ml}\right)$ & 0 \\
G2 $\left(6.010^{8} \mathrm{UFC} / \mathrm{ml}\right)$ & 0 \\
G3 $\left(9.010^{8} \mathrm{UFC} / \mathrm{ml}\right)$ & $1.67 .10^{3}$ \\
G4(Distilled Water) & 0 \\
\hline
\end{tabular}

from the 1st to the 4 th day and from the 4th to the 7 th day (Fig. 10).

\section{Discussion}

In vitro anti-Salmonella activity of Uvaria chamae,

\section{Phyllantus amarus and Lantana camara}

The aqueous and ethanolic extracts of the leaves and bark of $U$. chamae showed an inhibition of Salmonella spp. with the exception of the ethanolic extract of $U$. chamae's roots. The aqueous extract of Uvaria chamae was active on $90 \%$ of the virulent Salmonella spp. and on Salmonella Typhimurium ATCC 14028. These results can be compared to those obtained by Ogueke [17]. This author showed that at a concentration varying between 150 and $250 \mathrm{mg} / \mathrm{ml}$, aqueous and ethanolic extracts of bark and the ethanolic extract of leaves of Uvaria chamae inhibited Salmonella Typhi.

Aqueous and ethanolic extracts of Phyllantus amarus inhibited Salmonella spp. with maximal inhibition diameter of $12 \mathrm{~mm}$. The activity of Phyllantus amarus extracts on Salmonella spp. were reported in 2008. Using agar cup diffusion method, the authors showed that ethanolic extracts of $P$. amarus were active on Salmonella Typhi [18]. In our study, only leaves ethanolic extract of Phyllantus amarus inhibit Salmonella Typhimurium ATCC 14028 $(9.33 \pm 1.53 \mathrm{~mm})$. The inhibitory power of the extract on the reference strain was greater than those obtained in a previous study. For concentrations ranging from 200 to $1000 \mu \mathrm{g} / \mathrm{ml}$, the inhibition diameters varied between 7 and $9 \mathrm{~mm}$ on Salmonella Typhimurium ATCC 6539 [19].

The ethanolic leaves extract of Lantana camara had an inhibition diameter of $8 \mathrm{~mm}$ on Salmonella Typhimurium ATCC 14028. The inhibitory power of extracts of Lantana camara on Salmonella spp. has already been reported in the literature. Lyumugabe et al. [20] obtained an inhibition diameter of $11 \mathrm{~mm}$ on Salmonella Typhimurium.

\section{Experimental infection of three-day-old chicks with Salmonella Typhimurium ATCC 14028: preliminary test}

To achieve an experimental infection requires that certain experimental conditions be met. The most important are the virulence of the strain used, the choice of the appropriate study model, the choice of the dose and the optimal infective concentration. The choice of chicks as a study model was motivated by two main reasons.

In this study, we choose three-day old chicks for various reasons. One had to choose an age of susceptibility, an age when the animal's immune system is not mature enough to prevent infection. Such an age guarantees the establishment of the infection. Also it is known that in poultry, the signs of the disease are rarely observed after the first 2 weeks of life [21]. These strategic choices appear to be optimal since, $24 \mathrm{~h}$ after the infection, the 
Table 5 Salmonellosis Symptoms in three-day-old chicks inoculated with Salmonella Typhimurim ATCC 14028 and treated with Leaves aqueous extract of U. Chamae and Colistin ( $n=18$ for each group)

\begin{tabular}{|c|c|c|c|c|c|c|c|c|c|c|}
\hline \multirow[t]{2}{*}{ Groups } & \multirow[t]{2}{*}{ Salmonellosis symptoms } & \multicolumn{9}{|c|}{ Days Post infection } \\
\hline & & 1 & 2 & 3 & 4 & 5 & 6 & 7 & 8 & $\overline{9}$ \\
\hline \multirow[t]{3}{*}{ G1 (non-infected and non-treated) } & Wet cloaca & - & - & - & - & - & - & - & - & - \\
\hline & diarrheal stool & - & - & - & - & - & - & - & - & - \\
\hline & Somnolence & - & - & - & - & - & - & - & - & - \\
\hline \multirow[t]{3}{*}{ G2 (infected and untreated) } & Wet cloaca & + & + & + & + & + & + & + & + & + \\
\hline & diarrheal stool & + & + & + & + & + & + & + & + & + \\
\hline & Somnolence & - & + & + & + & + & + & - & - & - \\
\hline \multirow[t]{3}{*}{ G3 (Infected and treated with 200 mg/l of Colistin) } & Wet cloaca & + & + & + & + & + & - & - & - & - \\
\hline & diarrheal stool & + & + & + & + & + & + & - & - & - \\
\hline & Somnolence & + & + & + & - & - & - & - & - & - \\
\hline \multirow[t]{3}{*}{ G4 (infected and treated with $100 \mathrm{mg} / \mathrm{l}$ of Uvaria chamae leaves aqueous extract) } & Wet cloaca & + & + & + & + & + & + & - & - & - \\
\hline & diarrheal stool & + & + & + & + & + & + & + & + & - \\
\hline & Somnolence & + & + & + & - & - & - & - & - & - \\
\hline \multirow[t]{3}{*}{ G5 (infected and treated with $200 \mathrm{mg} / \mathrm{l}$ of Uvaria chamae leaves aqueous extract) } & Wet cloaca & + & + & + & + & + & + & + & - & - \\
\hline & diarrheal stool & + & + & + & + & + & + & - & - & - \\
\hline & Somnolence & + & + & - & - & - & - & - & - & - \\
\hline \multirow[t]{3}{*}{ G6 (infected and treated with $400 \mathrm{mg} / \mathrm{l}$ of Uvaria chamae leaves aqueous extract) } & Wet cloaca & + & + & + & + & + & + & - & - & - \\
\hline & diarrheal stool & + & + & + & + & + & + & + & - & - \\
\hline & Somnolence & + & + & + & + & - & - & - & - & - \\
\hline
\end{tabular}

Table 6 Salmonellosis Symptoms in three-day-old chicks inoculated with P19 Salmonella spp strain and treated with Leaves aqueous extract of $U$. Chamae and Colistin ( $n=18$ for each group)

\begin{tabular}{|c|c|c|c|c|c|c|c|c|c|c|}
\hline \multirow[t]{2}{*}{ Groups } & \multirow[t]{2}{*}{ Salmonellosis symptoms } & \multicolumn{9}{|c|}{ Days Post infection } \\
\hline & & 1 & 2 & 3 & 4 & 5 & 6 & 7 & 8 & \\
\hline \multirow[t]{3}{*}{ G1 (non-infected and non-treated) } & Wet cloaca & - & - & - & - & - & - & - & - & - \\
\hline & diarrheal stool & - & - & - & - & - & - & - & - & 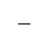 \\
\hline & Somnolence & - & - & - & - & - & - & - & - & 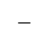 \\
\hline \multirow[t]{3}{*}{ G2 (infected and untreated) } & Wet cloaca & + & + & + & + & + & + & + & + & + \\
\hline & diarrheal stool & + & + & + & + & + & + & + & + & 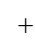 \\
\hline & Somnolence & + & + & + & + & - & - & - & - & 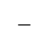 \\
\hline \multirow[t]{3}{*}{ G3 (Infected and treated with 200 mg/l of Colistin) } & Wet cloaca & + & + & + & + & + & + & - & - & - \\
\hline & diarrheal stool & + & + & + & + & + & + & - & - & - \\
\hline & Somnolence & + & + & + & + & - & - & - & - & - \\
\hline \multirow[t]{3}{*}{ G4 (infected and treated with $100 \mathrm{mg} / \mathrm{l}$ of Uvaria chamae leaves aqueous extract) } & Wet cloaca & + & + & + & + & + & + & + & - & 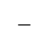 \\
\hline & diarrheal stool & + & + & + & + & + & + & + & + & + \\
\hline & Somnolence & + & + & + & - & - & - & - & - & - \\
\hline \multirow[t]{3}{*}{ G5 (infected and treated with 200 mg/l of Uvaria chamae leaves aqueous extract) } & Wet cloaca & + & + & + & + & - & - & - & - & - \\
\hline & diarrheal stool & + & + & + & + & + & + & - & - & - \\
\hline & Somnolence & + & + & + & - & - & - & - & - & - \\
\hline \multirow[t]{3}{*}{ G6 (infected and treated with $400 \mathrm{mg} / \mathrm{l}$ of Uvaria chamae leaves aqueous extract) } & Wet cloaca & 3 & - & - & - & - & - & - & - & - \\
\hline & diarrheal stool & + & + & + & + & + & + & - & - & \\
\hline & Somnolence & + & + & - & - & - & - & - & - & \\
\hline
\end{tabular}


Table 7 Evolution of faeces aspect from three-day-old chicks inoculated with Salmonella Typhimurim ATCC 14028 and treated with Leaves aqueous extract of U. chamae and Colistin

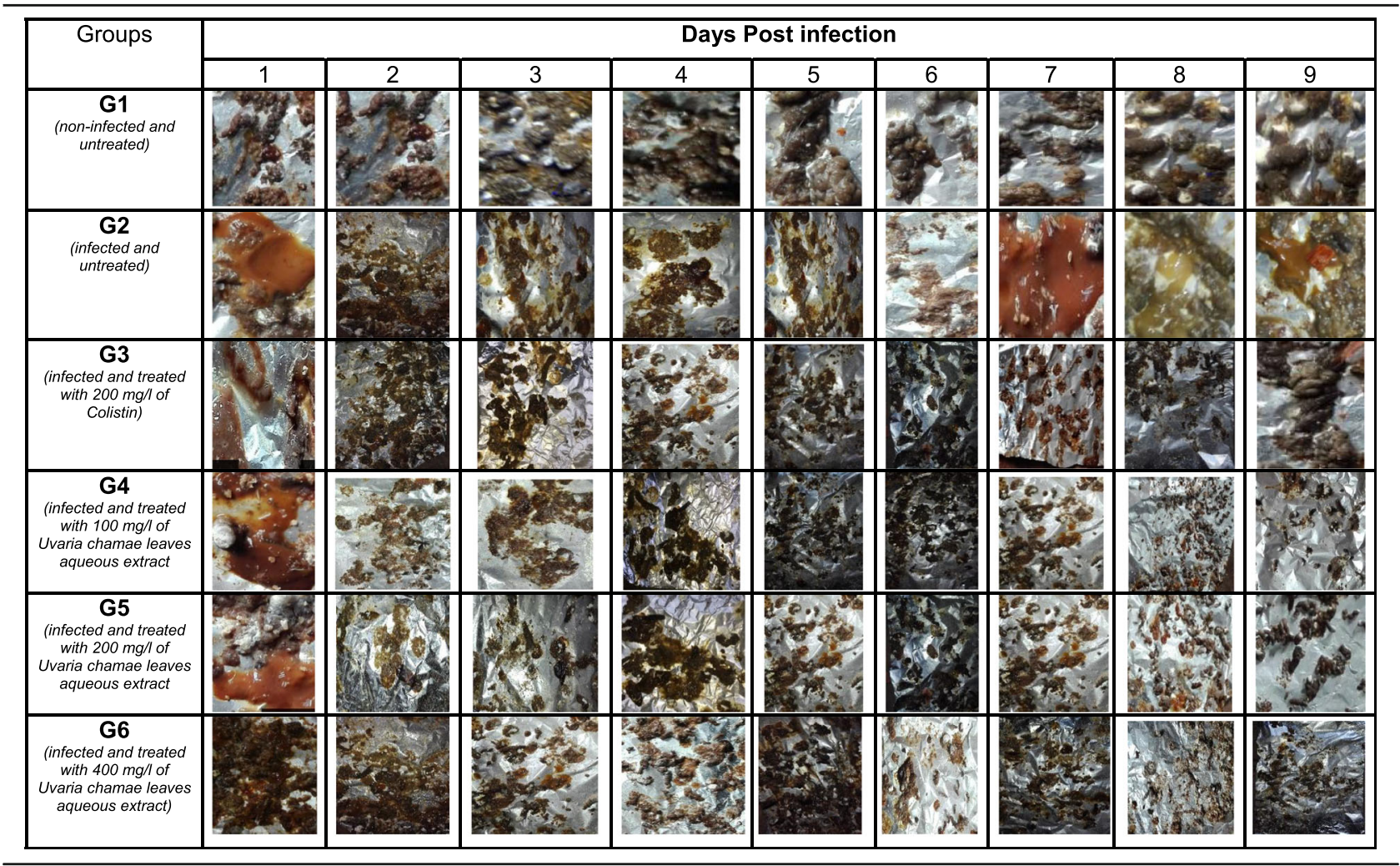

animals showed signs of salmonellosis, particularly in groups 2 and 3, which received the concentrations of inoculum 2 and 3 respectively. It was observed wet cloaca, diarrhea stool and somnolence. Clinical signs have been associated with the detection of salmonella in feces. The chosen model has therefore made it possible to reproduce the disease. Several studies have focused on the use of chicks at an age of susceptibility to optimize infection. Osman et al. [22] used 1-day-old SPF White Leghorn chicks for inoculation with Salmonella Typhimurium. Beal et al. [23] confirmed that Salmonella Typhimurium is a non-pathogenic commensal in chickens greater than 3 days of age and can colonize the tract sub-clinically for 8-9 weeks after experimental infection. However, it is possible to use older birds and have interesting results. It all depends on the nature of the study, the virulence of the strain, the concentration and the infective dose. For example, Pande et al. [24] used with success henses of 14 weeks for oral induction with $S$. Typhimurium PT 9. The virulence of Salmonella Typhimurium ATCC 14028 was a guarantee because these virulence factors have been characterized by PCR by Deguenon et al. [25]. This study showed that the strain has at least 5 virulence genes: invA, spvR, SpvC, FimA and Stn. Spv genes are responsible for the systemic infection and multidrug resistance in humans and animals [26]. SpvC gene is able to inhibit the activation of macrophages [27]. Presence of fimA gene indicates the presence of fimbriae which is important for Salmonella spp. to adhere to epithelial cells [25].

Stn gene is suspected to contribute to enterotoxigenic potency [28]. The presence of all these genes therefore guarantees the pathogenicity of Salmonella Typhimurium and its ability to infect chicks.

This virulence explains why salmonellosis symptoms were observed in infected animals. Three infective concentrations were chosen because we had no assurance of sufficient bacterial load to induce salmonellosis in chicks of this age. We had to expand the possibilities. The results showed that only concentrations 2 and 3 could trigger the symptoms of salmonellosis. These symptoms were present until the 10th day of observation in the group 3 chicks while they disappeared between the fifth and the 7th day for the group 2. Salmonella spp. were investigated in faecal specimens to support clinical observations. Salmonella spp. were detected in chicks of group 2 and 3, 3 days after infection. Chickens infected with concentration 3 of inoculum still host Salmonella.

By relating microbiological data to clinical observations, it seems obvious that only the infective 3 concentration was able to keep the 3-day-old chicks sicked for 10 days. This observation was reinforced by the count at 
Table 8 Evolution of faeces aspect from three-day-old chicks inoculated with P19 Salmonella strain and treated with Leaves aqueous extract of $U$. chamae and Colistin

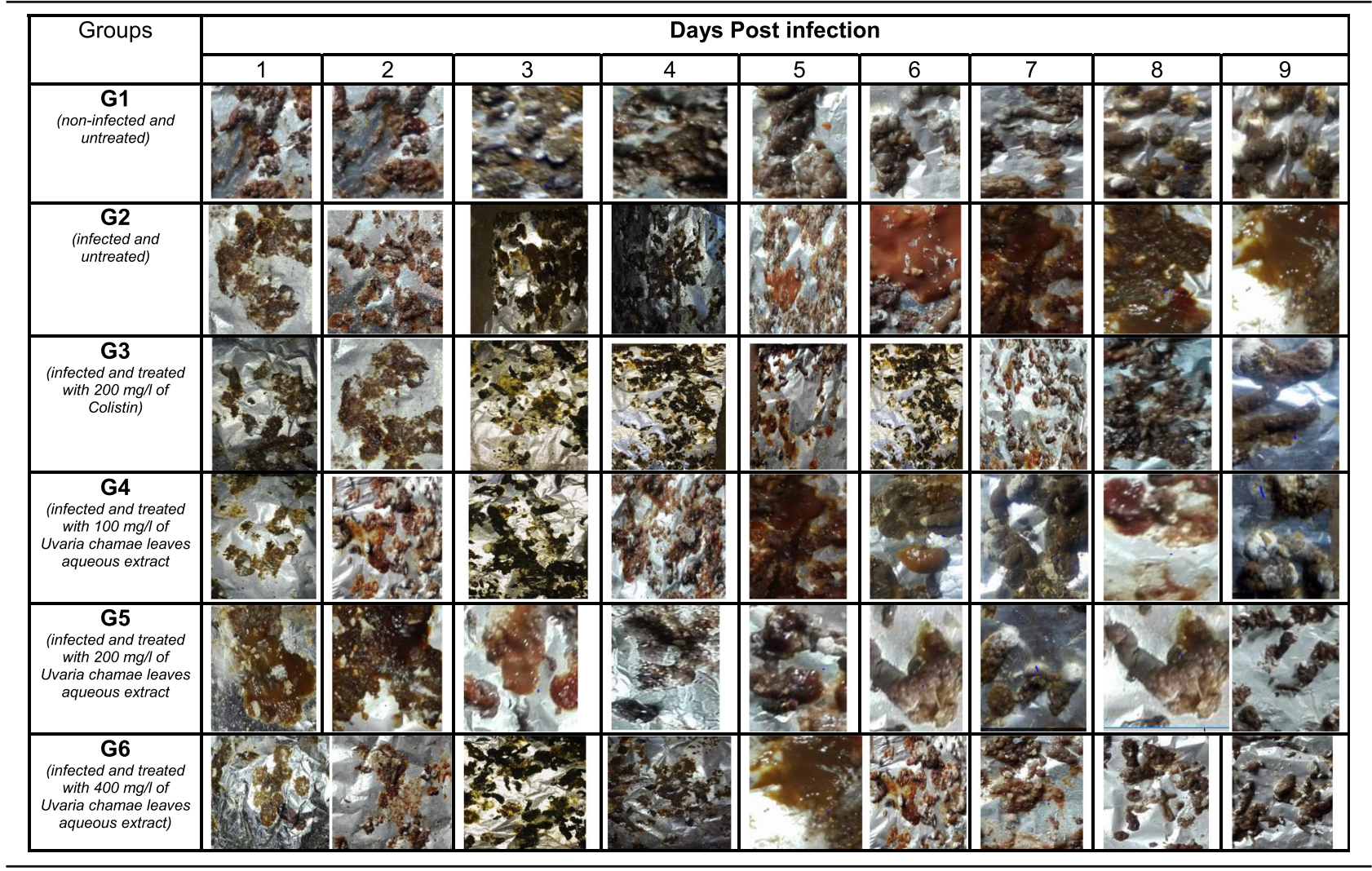

day 9. The disappearance of Salmonella in group 2 could be explained by a positive reaction of the immune system of the birds.

\section{In vivo anti-Salmonella activity of Uvaria chamae using chick model}

Twenty-four hours after induction, symptoms were detected in all infected chicks. Diarrheal stools were abundant. The cloacae of the chicks were wet and somnolence was noticed in some chicks. During the 9 days of monitoring, including 7 days of treatment, these symptoms evolved considerably according to the groups. They remained persistent in infected and untreated chicks. It is important to note that in these two lots, diarrhea was slightly reduced at the last days of monitoring. Also the other symptoms such as the appearance of the cloaca became less and less remarkable in certain chicks of the untreated group, even without treatment. This shows a progression of the disease to asymptomatic carriage. As many authors reported, in poultry, salmonellosis is often asymptomatic and symptoms are less and less remarkable after one to 2 weeks of life. But the chicks shed it in their feces. It is for this reason that the experiment was carried out on three-day-old chicks [29-32]. Similarly, this argument undermines the use of symptoms of salmonellosis to judge the efficacy of a therapeutic anti-salmonella substance in chicks. This is what led us to carry out the enumeration of salmonella.

Leaves aqueous extract of $U$. chamae inhibit Salmonella Typhimurium ATCC in chicks at 100, 200 and $400 \mathrm{mg} / \mathrm{L}$ but the bacterial load was not canceled. This confirms the in vitro anti-Salmonella tests results which showed that this extract has a bacteriostatic effect on Salmonella Typhimurium ATCC 14028. On the other hand, at 200 and $400 \mathrm{mg} / \mathrm{L}$, the extract showed a better in vivo activity than Colistin on virulent Salmonella spp P19. There is no scientific data on the in vivo activity of extracts of Uvaria chamae on Salmonella spp using chicks model. But interesting data exist about other natural substances. In a last study, Five-months-old local chickens, free of antibodies against fowl typhoid were used for challenge with Salmonella Gallinarum. Administration of extract of Aloe secundiflora showed increase in the levels of interleukin 6 (IL-6) [33].

The initial decrease in bacterial load of untreated chickens can be explain by the fact that the animals' immune system try to control the infection at first. But in the absence of immunity and specific treatment, bacteria continue to multiply, which increases the bacterial load. 
Table 9 Evolution of cloacal aspect from three-day-old chicks inoculated with Salmonella Typhimurium and treated with Leaves aqueous extract of $U$. chamae and Colistin

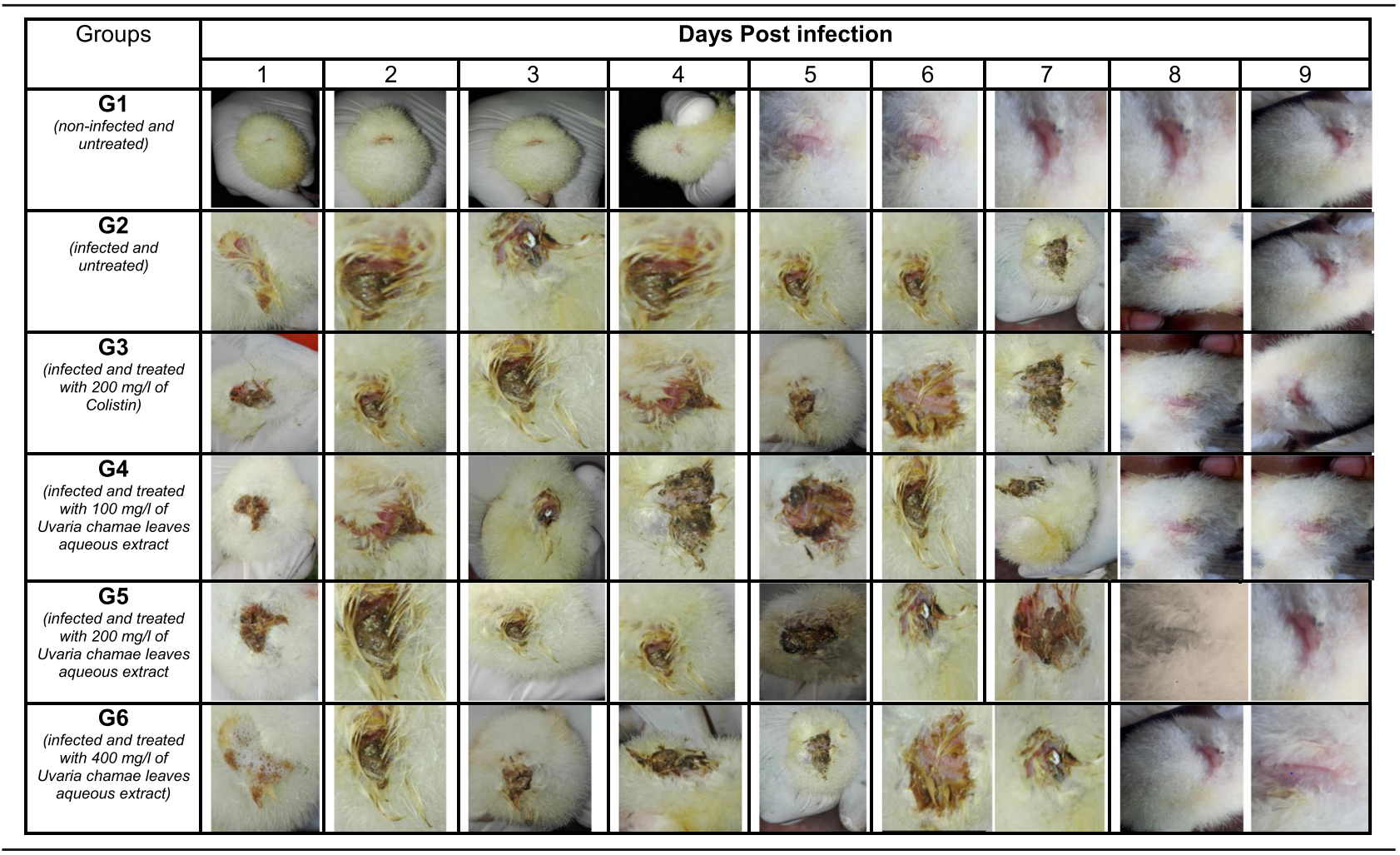

\section{Conclusions}

This study demonstrated the in vitro inhibitory potency of aqueous and ethanolic extracts of Uvaria chamae, Phyllantus amarus and Lantana camara on Salmonella spp. Leaves aqueous extract of $U$. chamae inhibit Salmonella Typhimurium ATCC 14028 and Salmonella spp. in chicks at 200 and $400 \mathrm{mg} / \mathrm{L}$. The extract showed no toxicity at the concentrations tested. This extract could be enhanced by the development of an improved traditional medicine for the management of non-typhoid salmonellosis.

\section{Methods}

Leaves of Lantana camara (Verbenaceae), Leaves and roots of Uvaria chamae (Annonaceae), Leaves of Phyllanthus amarus Schumach.\&.Thonn were collected from the wild. In Benin, no permission was necessary to collect these samples.

Identification was done at the Beninese National Herbarium (University of Abomey Calavi) by Professor Hounnankpon YEDOMONHAN (https://chercheurs. inrab.org/details/173).

Reference numbers in the herbarium are AA6686/ HNB for Phyllantus amarus, AA6687/HNB for Uvaria chamae, AA6688/HNB for Lantana camara. This experimental research has been done in compliance with our institution (University of Abomey-Calavi), national and international guidelines. All the plants collected in this study have been replaced by young ones in order to maintain the species survival

Two hundred ten three-day old and 90 three-week old Isa Brown male chicks were used for the experimentation. The birds were taken from a commercial hatchery "Terre et Associés", Abomey-Calavi (Benin). The birds were kept in an enclosure carefully cleaned and disinfected. During the experiment, the animals took water and feed. All experiments were conducted according to the protocol approved by Ethical committee of Research Unit of Applied Microbiology and Pharmacology of natural substances. After the procedure, animals were killed in compliance with the Beninese code for the care and use of animals for scientific purposes. All animal restraint for killing was ethically carried out carefully to avoid fear, distress or pain. In order to limit fear, distress or pain related to restraint, ketamine was administered to animals.

Eleven bacterial strains were used:

- Salmonella Typhimurium ATCC 14028 was acquired from Research Unit in Applied Microbiology and Pharmacology of natural substances, University of Abomey-Calavi, Benin. 
Table 10 Evolution of cloacal aspect from three-day-old chicks inoculated with P19 Salmonella and treated with Leaves aqueous extract of U. Chamae and Colistin

\begin{tabular}{|c|c|c|c|c|c|c|c|c|c|}
\hline \multirow[t]{2}{*}{ Groups } & \multicolumn{9}{|c|}{ Days Post infection } \\
\hline & 1 & 2 & 3 & 4 & 5 & 6 & 7 & 8 & 9 \\
\hline $\begin{array}{c}\mathbf{G 1} \\
\text { (non-infected and } \\
\text { untreated) }\end{array}$ & & & & & & & & & \\
\hline $\begin{array}{c}\mathbf{G 2} \\
\text { (infected and } \\
\text { untreated) }\end{array}$ & & & & & & & & & \\
\hline $\begin{array}{c}\mathbf{G 3} \\
\text { (infected and treated } \\
\text { with } 200 \mathrm{mg} / \text { of } \\
\text { Colistin) }\end{array}$ & & & & & & & & & \\
\hline $\begin{array}{c}\mathbf{G 4} \\
\text { (infected and treated } \\
\text { with } 100 \mathrm{mg} / \mathrm{l} \text { of } \\
\text { Uvaria chamae leaves } \\
\text { aqueous extract }\end{array}$ & & & & & & & & & \\
\hline $\begin{array}{c}\mathbf{G 5} \\
\text { (infected and treated } \\
\text { with } 200 \mathrm{mg} / \mathrm{l} \text { of } \\
\text { Uvaria chamae leaves } \\
\text { aqueous extract }\end{array}$ & & & & & & & & & \\
\hline $\begin{array}{c}\mathbf{G 6} \\
\text { (infected and treated } \\
\text { with } 400 \mathrm{mg} / \mathrm{l} \text { of } \\
\text { Uvaria chamae leaves } \\
\text { aqueous extract) }\end{array}$ & & & & & & & & & \\
\hline
\end{tabular}

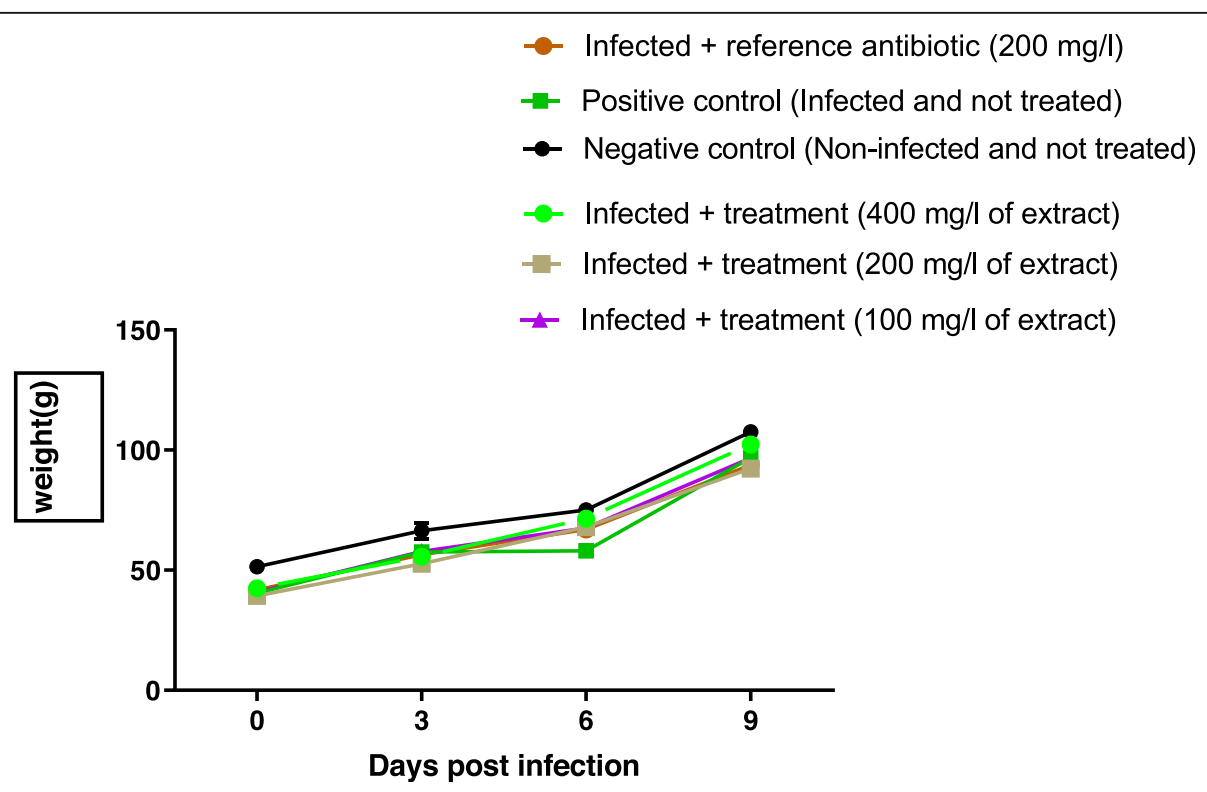

Fig. 3 weight changes of chicks orally infected with Salmonella Typhimurium 14028 and treated with leaves aqueous extract of U. chamae and Colistin 


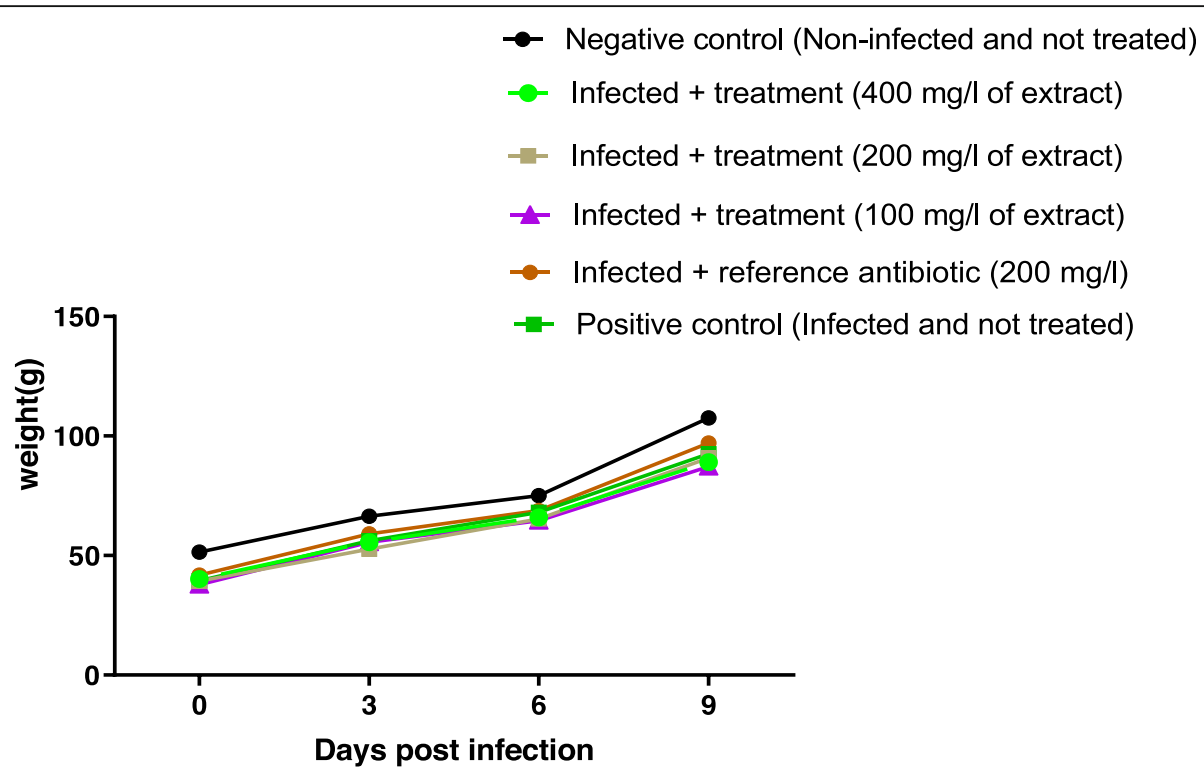

Fig. 4 Weight changes of chicks orally infected with Salmonella spp. (P19) and treated with leaves aqueous extract of U. chamae and Colistin

- Ten multiresistant strains of Salmonella spp: they were isolated by Deguenon et al. [25]. The strains were multidrug-resistant to penicillins, first generation cephalosporins and some aminoglycosides.

\section{Production of aqueous and ethanolic extracts}

Method described by Legba et al. [16] were used. After their collection, the organs (leaves and root) were dried at a temperature of $16^{\circ} \mathrm{C}$ in the laboratory. Powdering was performed using a Retsch SM 2000/1430/Upm/Smf type mill.

The extraction is performed by macerating fifty grams of dried powder in $500 \mathrm{ml}$ of ethanol or distilled water on a Stuart Bioblock Scientific Fisher stirrer for $72 \mathrm{~h}$. Then, the homogenate was filtered three time with hydrophilic cotton and once with Wattman paper. The filtrate obtained was dried at $40^{\circ} \mathrm{C}$ for ethanolic extract and $50^{\circ} \mathrm{C}$ for aqueous extract in the Pasteur oven.

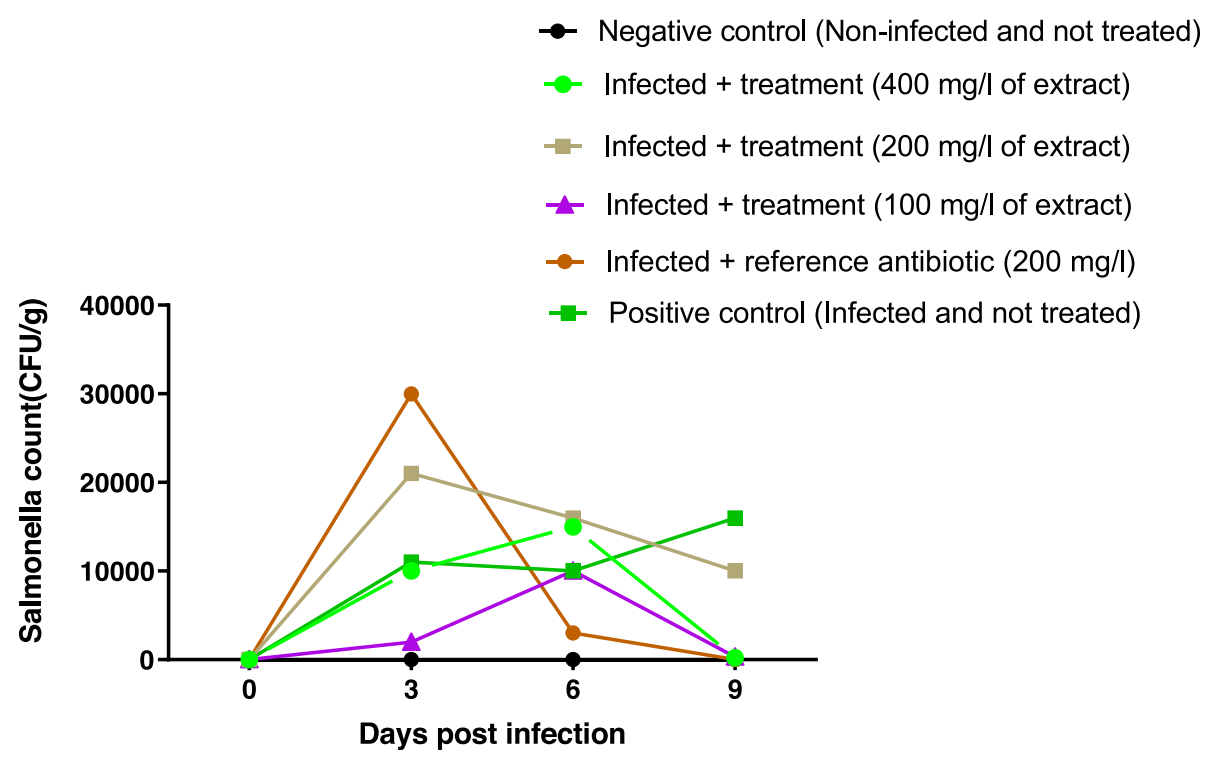

Fig. 5 Enumeration of Salmonella from feces of chicks orally infected with S. Typhimurium 14028 and treated with leaves aqueous extract of U.chamae and Colistin 


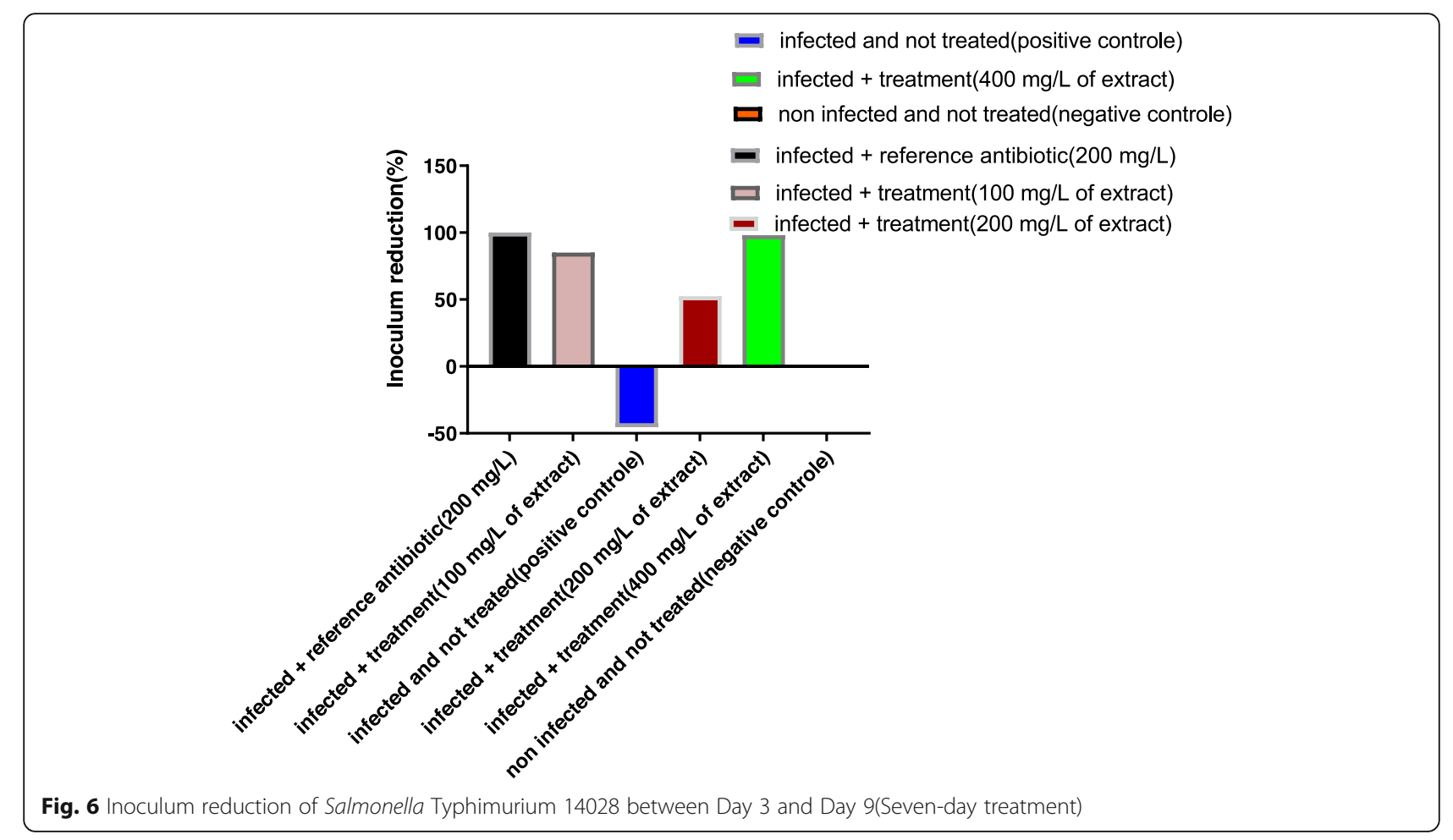

In vitro anti-Salmonella assessment of aqueous and ethanolic extract of Uvaria chamae, Phyllantus amarus and Lantana camara

Salmonella Typhimurium 14,028 and the ten multiresistant Salmonella spp. were used. Inoculum was obtained by emulsifying a 24-h pure colony of each strain from the
Mueller Hinton (MH) medium in physiological water $(5 \mathrm{ml})$. A turbidity of $0.5 \mathrm{Mc}$ Farland is obtained [16].

Using swab, each inoculum was seeded on Petri dishes containing $\mathrm{MH}$ agar. Sterile Pasteur pipette tip is then used to hollow out $6 \mathrm{~mm}$ Wells. $50 \mu \mathrm{l}$ of each extract were taken and deposited in the wells. Negative control

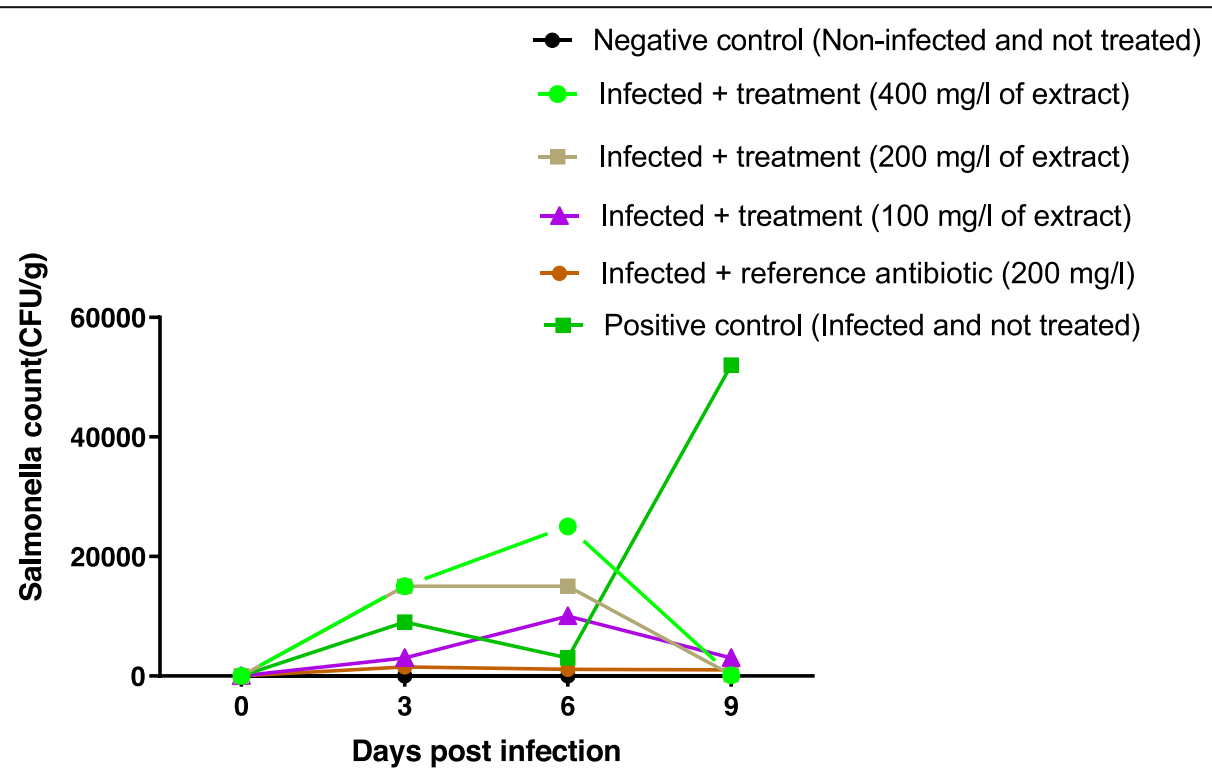

Fig. 7 Enumeration of Salmonella from faeces of chicks orally infected with Salmonella spp. (P19) and treated with leaves aqueous extract of U. chamae and Colistin 


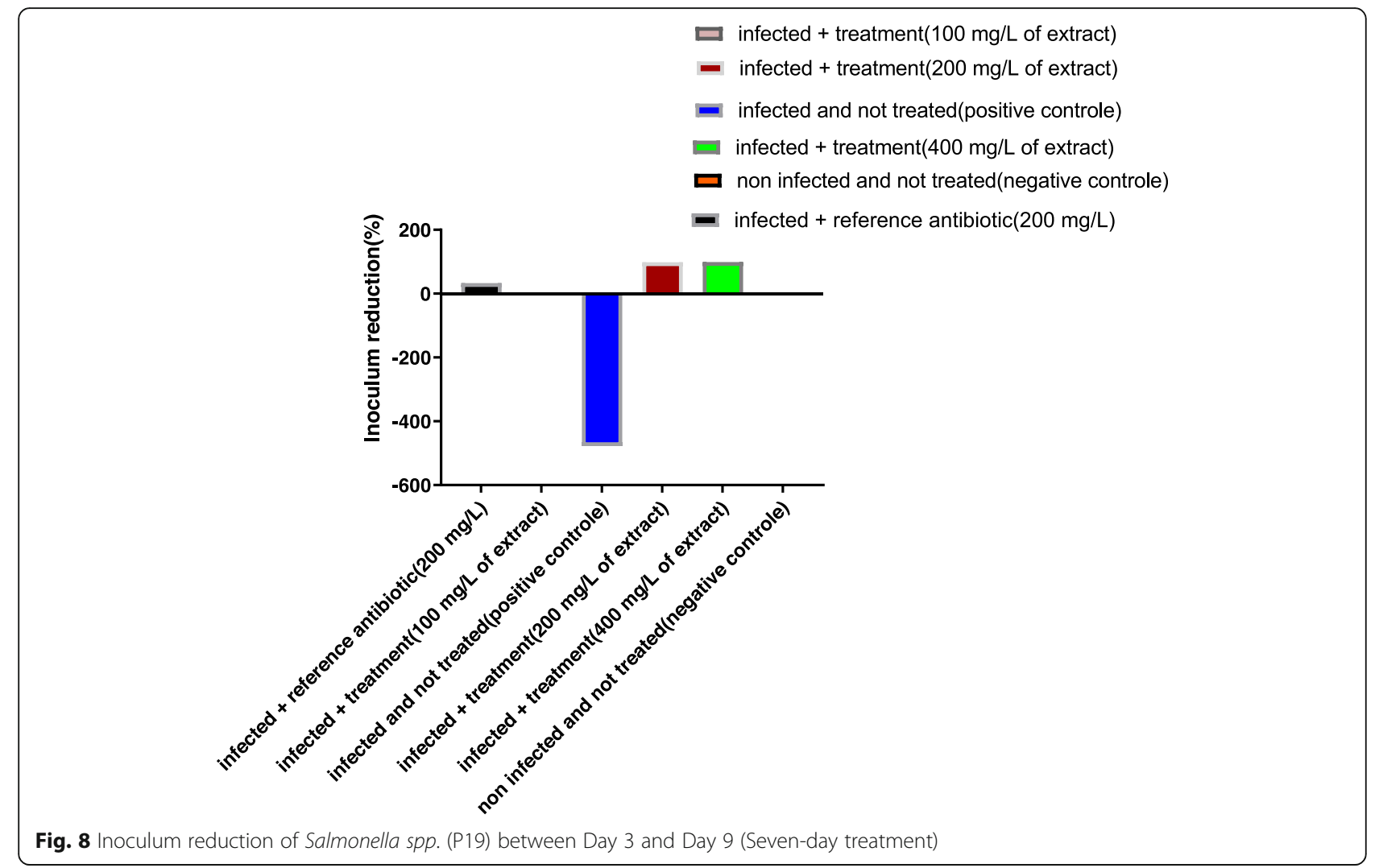

was constituted by well which contain sterile distilled water. After $1 \mathrm{~h}$ pre-diffusion at room temperature, the petri dish was incubated at $37^{\circ} \mathrm{C}$. After $24 \mathrm{~h}$ of incubation, the dish was examined and the zones of inhibition were measured [16].

Method used by Legba et al. [33] were used for determination of Minimal Inhibitory Concentration (MIC) and Minimal Bactericidal Concentration (MBC). Each extract were prepared at $200 \mathrm{mg} / \mathrm{ml} .100 \mu \mathrm{l}$ of the stock solution were added to $100 \mu \mathrm{l}$ of $\mathrm{MH}$ Broth. A series of two-fold dilution was made from well to well, then $100 \mu \mathrm{l}$ of different inoculum were added. Positive and negative controls were constituted respectively by adding $100 \mu \mathrm{l}$ of $\mathrm{MH}$ broth to $100 \mu \mathrm{l}$ of inoculum and $100 \mu \mathrm{l}$ of $\mathrm{MH}$ broth to $100 \mu \mathrm{l}$ of the extract. The plates were incubated at $37^{\circ} \mathrm{C}$ in bacteriological oven. The MIC was estimated after $24 \mathrm{~h}$ of incubation using Tetrazolium. For MBC determination, the content of each well was cultured on $\mathrm{MH}$ Agar and incubated at $37^{\circ} \mathrm{C}$ for $24 \mathrm{~h}$. The lowest concentration of extract for which no colony of bacteria is observed is MBC. The formula CMB/CMI was used to calculate the antibiotic potency (a.p) of each extract.

\section{Experimental infection of three-day-old Isa Brown male chicks with Salmonella Typhimurium ATCC 14028}

A preliminary microbiological examination of the cloaca of the chicks helped to check if chicks are exempt from
Salmonella spp. A cloaca swab was performed on all chicks and Salmonella spp were searched according to the method described by Deguenon et al. [25].

Salmonella inoculums were prepared from a pure isolate of the bacterial strain in distilled water at three selected concentrations: $3 \times 10^{8} \mathrm{CFU}$ (Concentration 1), $6 \times 10^{8} \mathrm{CFU}$ (Concentration 2), $9 \times 10^{8} \mathrm{CFU}$ (Concentration 3).

- Groups $1(n=3): 2 \mathrm{ml}$ of Inoculum concentration 1

- Groups $2(n=3): 2 \mathrm{ml}$ of Inoculum concentration 2

- Groups $3(n=3): 2 \mathrm{ml}$ of Inoculum concentration 3

- Groups 4 $(n=3): 2 \mathrm{ml}$ of Distilled water

Oral inoculation was performed using 20-gauge feeding needle and disposal syringe. To confirm the viability of the strain used for inoculation, a sample of each inoculum (about $100 \mu \mathrm{l}$ ) was taken before and after oral administration for culture at $37{ }^{\circ} \mathrm{C}$ for $24-45 \mathrm{~h}$.

The birds were observed for 10 days and the symptoms of salmonellosis were recorded. On days 3,6 , and 9 , the feces from each lots of chicks were collected. Salmonella was sought using method described par Deguenon et al. [25]. Five (5) grams of fecal samples were transferred immediately following collection in $45 \mathrm{ml}$ of buffered peptone water. Samples were homogenized in the broth either by vortex mixer and then incubated for $18-24 \mathrm{~h}$ 


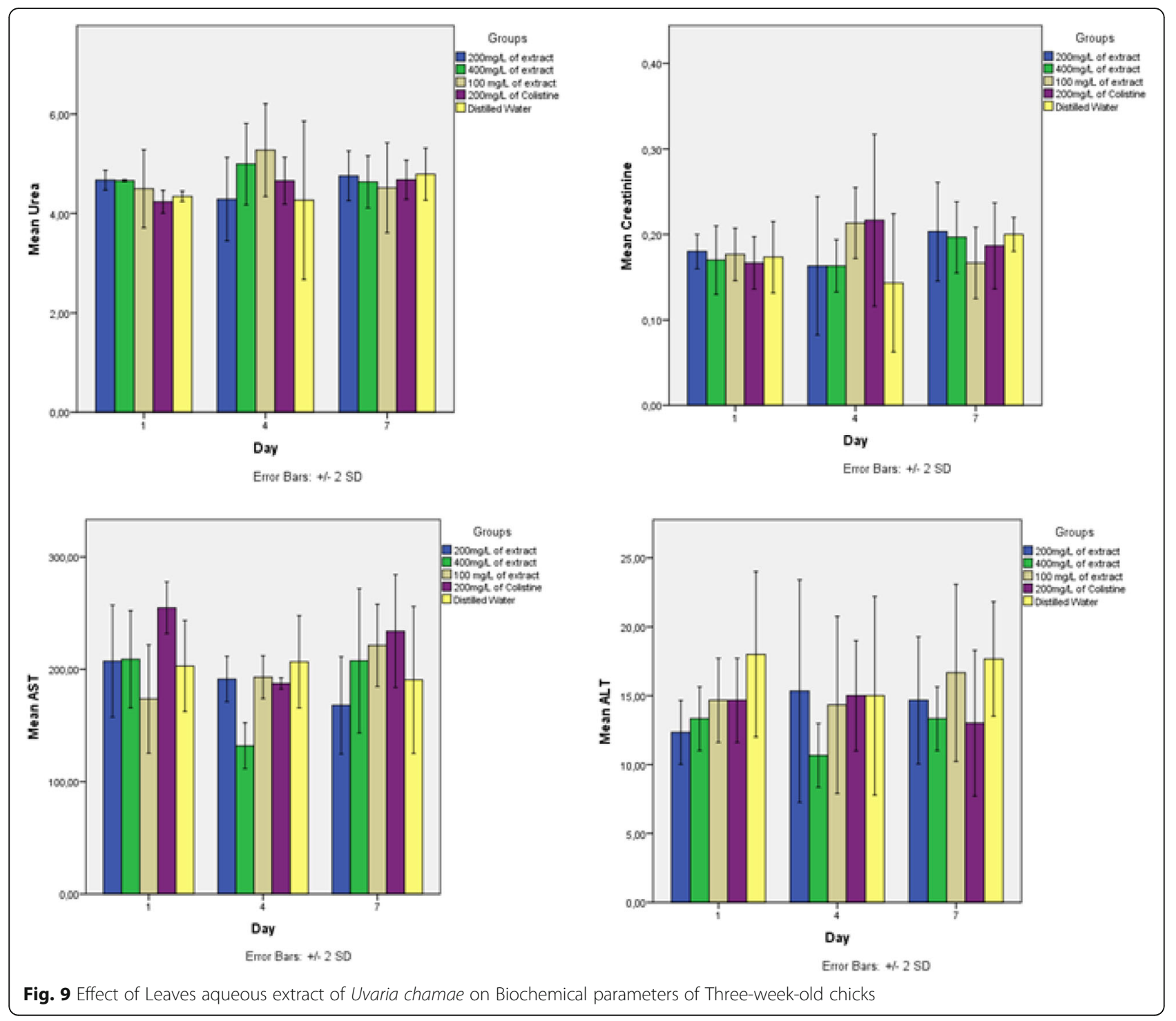

at $37^{\circ} \mathrm{C} .1 \mathrm{ml}$ of pre-enrichment was then inoculated in $9 \mathrm{ml}$ of selenite cystine broth for $24 \mathrm{~h}$. Isolation was done on petri-dishes containing Xylose Lysine Decarboxylase (XLD) and incubated for $24 \mathrm{~h}$. API 20E Gallery was used for positive identification of all suspicious colonies from fecal material. Salmonella counts were performed on Day 9 samples to assess bacterial load. The method described by Pande et al. [24].

\section{In vivo anti-Salmonella assessment of leaves aqueous extract of Uvaria chamae}

Salmonella Typhimurium 14,028 and Salmonella spp. (P19) were used for this step. After inoculation, chicks were treated with leaves aqueous extract of Uvaria chamae and colistin.

For each strain, 90 three-day-old chicks were randomly assorted into six groups:
- Group 1: non-infected and non-treated (G1, $n=18)$

- Group 2: infected and untreated (G2, $n=18)$

- Group 3: infected and treated with $200 \mathrm{mg} / \mathrm{l}$ of Colistin (G3, $n=18$ )

- Group 4: infected and treated with $100 \mathrm{mg} / \mathrm{l}$ of Uvaria chamae leaves aqueous extract $(\mathrm{G} 4, n=18)$

- Group 5: infected and treated with $200 \mathrm{mg} / \mathrm{l}$ of Uvaria chamae leaves aqueous extract $(\mathrm{G} 5, n=18)$

- Group 6: infected and treated with $400 \mathrm{mg} / \mathrm{l}$ of Uvaria chamae leaves aqueous extract $(\mathrm{G} 6, n=18)$.

Preliminary examination and inoculation were performed as previously but a single concentration of inoculum were used: $9.010^{8} \mathrm{UFC} / \mathrm{ml}$. The birds were observed for 9 days and the symptoms of salmonellosis were recorded. From the third day after infection, the chicks are subjected to oral treatment with the aqueous 


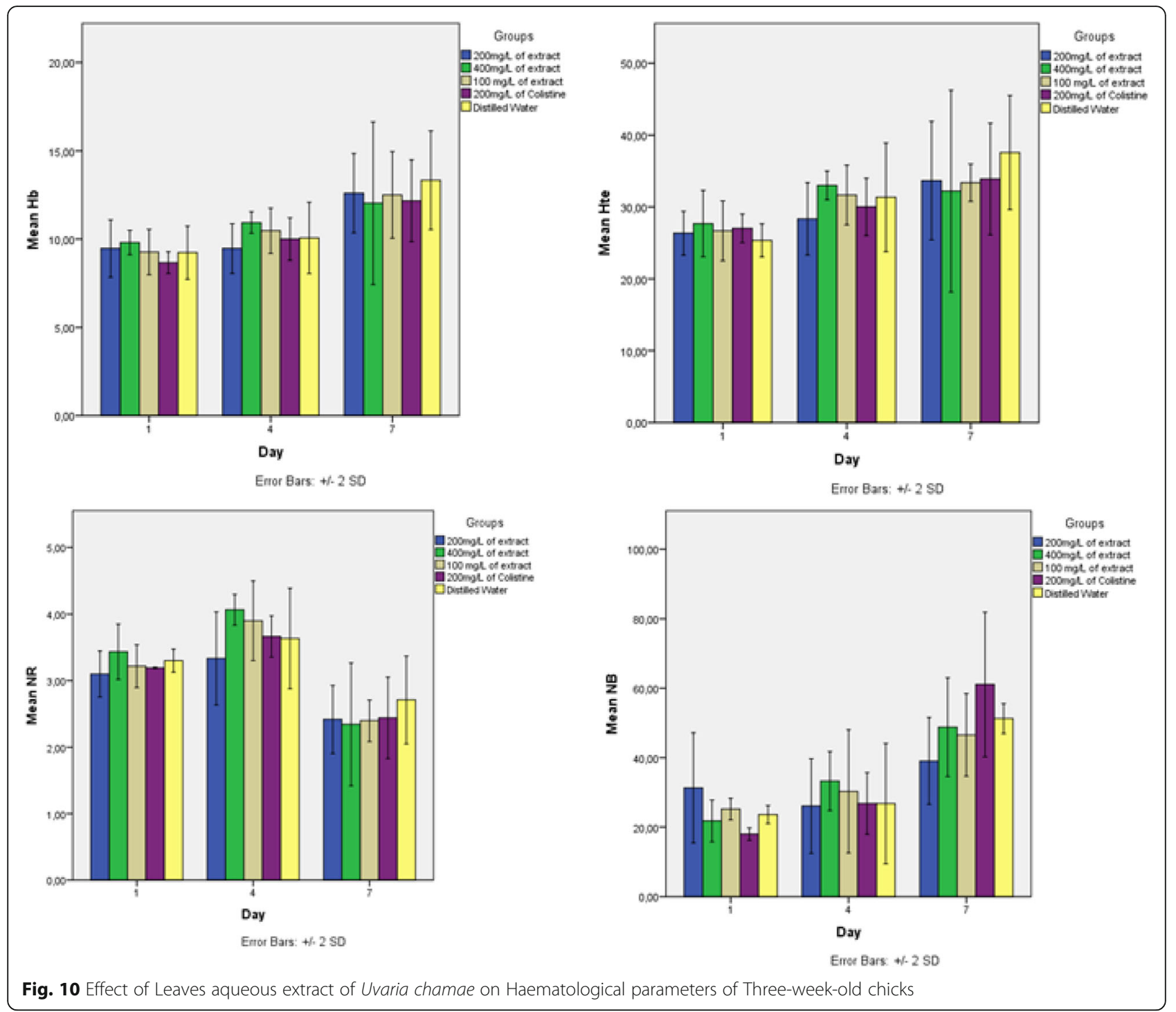

leaf extract of Uvaria chamae and colistin as reference antibiotic. The treatment was done for 7 days. On days 3, 6 and 9 after infection, faeces from each group were collected and Salmonella counts were performed [34].

\section{Effects of leaves aqueous extract of Uvaria chamae on biochemical and hematological parameters}

In order to evaluate the toxicity of Uvaria chamae leaves aqueous extracts for chicks, the different concentrations of extracts tested and Colistin were administered for 7 days to three-week-old chicks.

Ninety three-week-old Isa Brown male chicks were divided in five groups:

- Group 1: oral administration of $100 \mathrm{mg} / \mathrm{L}$ of Leaves aqueous extract of $U$. chamae $(\mathrm{G} 1, \mathrm{n}=18)$

- Group 2: oral administration of $200 \mathrm{mg} / \mathrm{L}$ of Leaves aqueous extract of U.chamae $(\mathrm{G} 2, \mathrm{n}=18)$
- Group 3: oral administration of $400 \mathrm{mg} / \mathrm{L}$ of Leaves aqueous extract of U.chamae $(\mathrm{G} 3, \mathrm{n}=18)$

- Group 4: oral administration of Colistin $(\mathrm{G} 4, \mathrm{n}=18)$

- Group 5: water

The hematological (white cell Number (NB); Blood red Cell (NR), Hemoglobin (Hb), Hematocrit (Hte) and biochemical (Uremia, creatinine, AST and ALT) data were recorded on Days 0, 4 and 7.

\section{Euthanasia}

For euthanasia, we used a technique from the "Guidelines for the Euthanasia of Animals, and the 2016 Canadian Code of Practice for the care and handling of Hatching Eggs, Breeders, Chickens and Turkeys" [35]. Since the animals are chicks, the most recommended method is carbon dioxide $\left(\mathrm{CO}_{2}\right)$ absorption. The chicks were exposed to carbon dioxide $\left(\mathrm{CO}_{2}\right)$ in a $\mathrm{CO}_{2}$ 
chamber. A heater coil has been added to the supply line in order to prevent interruption of gas due to freezing. Confirmation of euthanasia have been done on every chick, using lack of nictitating membrane reflex. Dilated and fixed pupil served as a sign of unconsciousness and/ or death [35]. When removed from the chamber, a secondary method of euthanasia before birds regain consciousness if the birds are not dead. Then, $80 \mathrm{mg}$ per weight kilogram of Sodium thiopental (intravenous injection) were administered to them.

\section{Statistical analysis}

Microbiological data were analyzed using ANOVA test with Graph Pad Prism 7.0 Software. Hematological and Biochemical data were analyzed by the SPSS 17.0 Software.

\begin{abstract}
Abbreviations
a.p: Antibiotic potency; ALT: Alanine aminotransferase; ANOVA: Analysis of Variance; API: Analytical Profile Index; AST: Aspartate transaminase;

ATCC: American Type Culture Collection; CFU: Colony forming unit; G: Group HNB: National Herbarium of Benin; MBC: Minimum Bactericidal

Concentration; MH: Mueller Hinton; MIC: Minimum Inhibitory Concentration P9, P70, P16, P14, P15, P19, P362, P368, P17, P29: Salmonella samples identification code; PCR: Polymerase chain reaction; SPF: Specific-PathogenFree; SPSS: Statistical Package for the Social Sciences; ST: Salmonella Typhimurium; TWAS: The World Academy of Sciences; UNESCO: United Nations Educational, Scientific and Cultural Organization; XLD: Xylose Lysine Decarboxylase
\end{abstract}

\section{Acknowledgements}

Authors are very grateful to Dr. Jerrold AGBANKPE and M. Arnaud SOHA for their contributions during the implementation of this study. They thank Professor Phyllis ADDO from whom the corresponding author learned the in vivo induction of salmonellosis in animals. They are also grateful to The World Academy of Sciences (TWAS) and the United Nations Educational, Scientific and Cultural Organization (UNESCO). These two institutions have allocated research funding to the research team under the number 487RG/ BIO/AF/AC G-FR3240293303. They have reviewed the research protocol and validated the design of the study and collection, analysis, and interpretation of data. The authors thank the Benin Centre for Scientific Research and Innovation for its financial support about this study. Through its Executive Committee, the Benin Centre for Scientific Research and Innovation has reviewed the research protocol and improved its implementation. The authors are finally grateful to the African-German Network of Excellence in Science (AGNES), the Alexander von Humboldt Foundation (AvH) and the German Ministry of Education and Research (BMBF) for the Junior Researcher Grant-PAWS (JRG-PAWS) 2019 awarded to Dr Esther DEGUENON. This grant was useful for this publication's writing and submission.

\section{Authors' contributions}

$B L, V D, C G, A A, E D, L B-M, M K$ and JD wrote and reviewed the protocol. VD got the funding. $B L, V D, C G, A A$, and $E D$ processed laboratory works. VD, YC did the statistical analyses. VD, BL wrote the draft of the manuscript. VD, JD, MK, YC and LB-M reviewed the manuscript. All authors have read and approved the manuscript.

\section{Authors' information}

$\mathrm{BL}$ is a researcher (PhD) in Microbiology, Biochemistry and Pharmacology of Natural Substances at University of Abomey-Calavi. He focuses on using natural substances to fight antimicrobial resistance. AA and CG work as junior researchers at Research Unit of Applied Microbiology and Pharmacology of natural substances, Polytechnic School of Abomey-Calavi (Benin). They focus on Microbiology and Molecular Biology. They are Master Students in Microbiology. ED is a researcher (PhD) at Research Unit of Applied Microbiology and Pharmacology of natural substances. She got her PhD degree in Molecular
Microbiology and Pharmacology of Natural Substances. She focuses on Salmonella spp. VD is a Senior Lecturer in Microbiology at the Polytechnic school of Abomey-Calavi, University of Abomey-Calavi. He is the Project Manager and founding member of the Research Unit in Applied Microbiology and Pharmacology of natural substances, Polytechnic School of Abomey-Calavi, University of Abomey-Calavi, Benin (www.e-urmapha.uac.bj). He got the grant which allowed this research and contributed to knowledge on using medicinal plants for medicinal treatment of salmonellosis in Benin. JD works as a Professor of Pharmacology and Animal Heath at the Department of Animal Health and Production, Polytechnic School of Abomey-Calavi, University of Abomey-Calavi, Benin. He is also Director of Research Unit of Applied Microbiology and Pharmacology of natural substances at University of Abomey-Calavi. LB-M works as Professor of Biochemistry, Microbiology and Molecular Biology at the Faculty of Sciences and Technology, University of Abomey-Calavi, Benin. YC is the Head of the Department of Drugs, Pharmacies and Diagnostic Explorations, Ministry of Health, Benin. He is a Pharmacist and got numerous interests in drugs based on medicinal plants. MK is the Head of the Beninese Center for Scientific Research and Innovation, Ministry of Higher Education and Scientific Research. He is Full Professor at the Polytechnic School of Abomey-Calavi, University of AbomeyCalavi, Benin.

\section{Funding}

The authors are very grateful to The World Academy of Sciences (TWAS) and the United Nations Educational, Scientific and Cultural Organization (UNESCO) under the number 487RG/BIO/AF/AC_G-FR3240293303. They are also grateful to Benin Centre of Scientific Research and Innovation for their financial support.

\section{Availability of data and materials}

All data generated or analyzed during this study is included in this published article and supplementary information files.

\section{Ethics approval and consent to participate}

The Benin National Ethical Committee for Health Research has reviewed and approved this study under No 65/MS/DC/SGM/DRFMT/CNERS/SA. Moreover, this study received ethical approval from Ethical committee of Research Unit of Applied Microbiology and Pharmacology of natural substances under the number 035-19/ URMAPHA/ EPAC/UAC

\section{Consent for publication}

Not applicable.

\section{Competing interests}

The authors declare that they have no competing interests.

\section{Author details}

${ }^{1}$ Research Unit in Applied Microbiology and Pharmacology of natural substances, Research Laboratory in Applied Biology, Polytechnic School of Abomey-Calavi, University of Abomey-Calavi, Cotonou, Benin. ${ }^{2}$ Laboratory of Biology and Molecular Typing in Microbiology, Faculty of Science and Technology, University of Abomey-Calavi, Cotonou, Benin. ${ }^{3}$ Department of Drugs, Pharmacies and Diagnostic Exploration, Ministry of Health, Cotonou, Benin. ${ }^{4}$ Beninese Center for Scientific Research and Innovation, Ministry of Higher Education and Scientific Research, Cotonou, Benin.

Received: 21 September 2019 Accepted: 27 January 2020

Published online: 10 February 2020

\section{References}

1. Jajere SM. A review of Salmonella enterica with particular focus on the pathogenicity and virulence factors, host specificity and antimicrobial resistance including multidrug resistance. Vet World. 2019;12:504-21.

2. Bhunia A. Foodborne microbial pathogens. New York: Springer New York; 2008. https://doi.org/10.1007/978-0-387-74537-4.

3. OMS. Statistiques sanitaires mondiales 20142014.

4. Majowicz S, Musto J, Scallan E, Angulo F, Kirk M, O'Brien S, et al. The global burden of nontyphoidal Salmonella gastroenteritis. - PubMed - NCBI. Clin Infect Dis. 2010;50:882-9.

5. Mouttotou N, Ahmad S, Kamran Z, Koutoulis KC. Prevalence, risks and antibiotic resistance of Salmonella in poultry production chain. In: Mares M, 
editor. Current Topics in Salmonella and Salmonellosis. InTech; 2017. https://doi.org/10.5772/67438

6. Eguale T. Non-typhoidal Salmonella serovars in poultry farms in Central Ethiopia: prevalence and antimicrobial resistance. BMC Vet Res. 2018;14:217.

7. Li B, Liu C, Liu L, Li S, Fan N, Hou H, et al. Prevalence and etiologic agent of Salmonella in livestock and poultry meats in Huai'an City during 2015-2016. Wei Sheng Yan Jiu. 2018;47:260-300.

8. Adhikari SK, Gyawali A, Shrestha S, Shrestha SP, Prajapati M, Khanal DR. Molecular confirmation of Salmonella typhimuriumin poultry from Kathmandu Valley. J Nepal Agric Res Counc. 2018:4:86-9.

9. Fagbamila IO, Barco L, Mancin M, Kwaga J, Ngulukun SS, Zavagnin P, et al. Salmonella serovars and their distribution in Nigerian commercial chicken layer farms. PLoS One. 2017;12:e0173097.

10. Iwamoto M, Reynolds J, Karp BE, Tate H, Fedorka-Cray PJ, Plumblee JR, et al. Ceftriaxone-resistant Nontyphoidal Salmonella from humans, retail meats, and food animals in the United States, 1996-2013. Foodborne Pathog Dis. 2017;14:74-83

11. Elkenany RM, Eladl AH, El-Shafei RA. Genetic characterisation of class 1 integrons among multidrug-resistant Salmonella serotypes in broiler chicken farms. J Glob Antimicrob Resist. 2018;14:202-8.

12. Voss-Rech D, Potter L, Vaz CSL, Pereira DIB, Sangioni LA, Vargas ÁC, et al, Antimicrobial resistance in Nontyphoidal Salmonella isolated from human and poultry-related samples in Brazil: 20-year meta-analysis. Foodborne Pathog Dis. 2017;14:116-24.

13. Michael GB, Schwarz S. Antimicrobial resistance in zoonotic nontyphoidal Salmonella : an alarming trend? Clin Microbiol Infect. 2016;22:968-74.

14. Boko C. Salmonella enterica dans les mortalités de pintadeaux au Bénin: Etude de terrain, comparaison des souches et activité antibactérienne des extraits de plantes locales: Sciences Vétérinaires. Belgium: Université de Liège; 2012

15. Dougnon V, Legba B, Yadouleton A, Agbankpe J, et al. Utilisation des plantes du Sud-Bénin dans le traitement de la fièvre typhoïde :rôle des herboristes. Utilisation des plantes du Sud-Bénin dans le traitement de la fièvre typhoïde : rôle des herboristes; 2018. p. 11.

16. Lègba B, Dougnon V, Ahoyo A, Agbankpè J, Hounmanou G, Aniambossou $A$, et al. Exploration of the antibacterial and chemical potential of some Beninese pharmacopoiea traditional plants. Microbiol Medica. 2018;32. https://doi.org/10.4081/mm.2017.6998.

17. Ogueke C. The Effects of Ethanolic and Boiling Water Extracts of Rootbarks and leaves of Uvaria chamae on some Hospital Isolates. J Am Sci. 2007;3(3): 68-73.

18. Oluwafemi F, Debiri F. Antimicrobial effect of Phyllanthus amarus and Parquetina nigrescens on Salmonella typhi. Afr J Biomed Res. 2008;11:215-9.

19. Mazumder A, Mahato A, Mazumder R. Antimicrobial potentiality of Phyllanthus amarus against drug resistant pathogens. Nat Prod Res. 2006;20 323-6.

20. Lyumugabe F, Primitive J, Bayingana C, Bajyana SE. Antimicrobial activity and phytochemicals analysis of Vernonia aemulans, Vernonia amygdalina, Lantana camara and Markhamia lutea leaves as natural beer preservatives. Am J Food Technol. 2017;12:35-42.

21. Elgroud R. Contaminations du poulet de chair par les salmonelles non typhiques en élevages et abattoirs de la wilaya de Constantine: Caractérisations phénotypiques et génotypiques par ERIC-PCR, IS-PCR et PFGE. Thèse pour l'obtention du diplôme de Doctorat en Sciences Vétérinaires. Algeria: Université Mentouri Constantine; 2009

22. Osman K, Moussa IM, Yousef AM, Aly M, Radwan M, Alwathnani H. Pathogenicity of some avian Salmonella serovars in two different animal models: SPF chickens and BALB/C mice; 2010.

23. Beal RK, Wigley P, Powers C, Hulme SD, Barrow PA, Smith AL. Age at primary infection with Salmonella enterica serovar Typhimurium in the chicken influences persistence of infection and subsequent immunity to rechallenge. Vet Immunol Immunopathol. 2004;100:151-64.

24. Pande W, Devon RL, Sharma P, McWhorter AR, Chousalkar KK. Study of Salmonella Typhimurium infection in laying hens. Front Microbiol. 2016;7. https://doi.org/10.3389/fmicb.2016.00203.

25. Deguenon E, Dougnon V, Lozes E, Maman N, Agbankpe J, Abdel-Massih RM, et al. Resistance and virulence determinants of faecal Salmonella spp. isolated from slaughter animals in Benin. BMC Res Notes. 2019;12. https://doi.org/10.1186/s13104-019-4341-x.
26. Chiu C-H, Su L-H, Chu C-H, Wang M-H, Yeh C-M, Weill F-X, et al. Detection of multidrug-resistant Salmonella enterica serovar typhimurium phage types DT102, DT104, and U302 by multiplex PCR. J Clin Microbiol. 2006;44:2354-8.

27. Guiney DG, Fierer J. The role of the spv genes in Salmonella pathogenesis. Front Microbiol. 2011;2:129.

28. Nakano M, Yamasaki E, Ichinose A, Shimohata T, Takahashi A, Akada JK, et al. Salmonella enterotoxin (Stn) regulates membrane composition and integrity. Dis Model Mech. 2012;5:515-21.

29. Sadeyen J-R, Trotereau J, Velge P, Marly J, Beaumont C, Barrow PA, et al. Salmonella carrier state in chicken: comparison of expression of immune response genes between susceptible and resistant animals. Microbes Infect. 2004;6:1278-86

30. Lalsiamthara J, Lee JH. Pathogenic traits of Salmonella Montevideo in experimental infections in vivo and in vitro. Sci Rep. 2017;7:1-12.

31. Demirbilek SK. Salmonellosis in Animals. Salmonella - A Re-emerging Pathogen; 2017. https://doi.org/10.5772/intechopen.72192.

32. Kogut MH, Arsenault RJ. Immunometabolic phenotype alterations associated with the induction of disease tolerance and persistent asymptomatic infection of Salmonella in the chicken intestine. Front Immunol. 2017;8. https://doi.org/10.3389/fimmu.2017.00372.

33. Waihenya R, Mtambo MMA, Nkwengulila G, Minga UM. Efficacy of crude extract of Aloe secundiflora against Salmonella gallinarum in experimentally infected free-range chickens in Tanzania. J Ethnopharmacol. 2002;79:317-23.

34. Choi J-G, Kang O-H, Lee Y-S, Chae H-S, Oh Y-C, Brice O-O, et al. In vitro and in vivo antibacterial activity of Punica granatum Peel ethanol extract against Salmonella. Evid Based Complement Alternat Med. 2011;2011:1-8.

35. Poultry Industry Council. Practical Guidelines for On-Farm Euthanasia of Poultry. 2016. https://www.poultryindustrycouncil.ca/wp-content/uploads/2 016/08/PIC-Practical-Guidelines-for-On-Farm-Euthanasia-of-Poultry.pdf.

\section{Publisher's Note}

Springer Nature remains neutral with regard to jurisdictional claims in published maps and institutional affiliations.

\section{Ready to submit your research? Choose BMC and benefit from:}

- fast, convenient online submission

- thorough peer review by experienced researchers in your field

- rapid publication on acceptance

- support for research data, including large and complex data types

- gold Open Access which fosters wider collaboration and increased citations

- maximum visibility for your research: over $100 \mathrm{M}$ website views per year

At $\mathrm{BMC}$, research is always in progress.

Learn more biomedcentral.com/submission 